\title{
Production, Purification and Characterisation of Keratinases From Bacillus species Isolated From Poultry Feather Waste
}

\author{
Michael Dada \\ Department Microbiology \\ University of Ibadan \\ Nigeria \\ dadamaikl@yahoo.com \\ Sherifah Wakil \\ University of Ibadan \\ Nigeria \\ shemowak@yahoo.com
}

DOI: 10.31364/SCIRJ/v8.i4.2020.P0420767

http://dx.doi.org/10.31364/SCIRJ/v8.i4.2020.P0420767

\begin{abstract}
Feather is high in protein (keratin) and is not easily degradable in nature. It is produced in large amounts as waste through poultry activities all over the world. In order to provide sufficient use for this keratin-rich waste the keratin present in feather can serve as keratinase inducer. Hence this study focuses on the production, purification and characterisation of keratinases from isolated keratin-degrading Bacillus licheniformis-K51, Bacillus subtilis-K50 and Bacillus sp.-K53. Bacillus licheniformis-K51 gave highest keratinolytic activity $(24.76 \pm 0.91 \mathrm{U} / \mathrm{mL})$ at $\mathrm{pH} 7.8,37^{\circ} \mathrm{C}$, agitation rate $150 \mathrm{rpm}$ and $0.3 \%\left(\mathrm{NH}_{4}\right)_{2} \mathrm{SO}_{4}$ on day 7 , while Bacillus subtilis-K50 had $19.03 \pm 0.74 \mathrm{U} / \mathrm{mL}$ at $\mathrm{pH} 7.5,37^{\circ} \mathrm{C}$, agitation rate $200 \mathrm{rpm}$ and $1.4 \%$ cellulose on day 4 . Bacillus sp.-K53 gave least activity $(18.41 \pm 0.60 \mathrm{U} / \mathrm{mL})$ at $\mathrm{pH} 7.2,37^{\circ} \mathrm{C}$ and agitation rate $150 \mathrm{rpm}$ on day 5. Molecular mass of purified keratinases was determined using sodium dodecyl sulfate polyacrylamide gel electrophoresis (SDS-PAGE) analysis and was obtained between 33-36 kDa. Purified enzyme of Bacillus licheniformis-K51 (EZYKer-51) contained Glutamate (18.2\%), Alanine (14.9\%) and showed highest activity $(26.31 \mathrm{U} / \mathrm{mL})$ at $60{ }^{\circ} \mathrm{C}$ and pH 8 with $\mathrm{K}_{\mathrm{M}}$ and $V_{\text {max }}$ kinetic constants of $25.60 \mathrm{mM}$ and $74.46 \mathrm{U} / \mathrm{mL}$, respectively.

The optimal conditions tested in this study can be useful parameters in the production of keratinases and also in applications that require the breakdown of keratin proteins
\end{abstract}

Key words: Keratin-degrading bacteria, Bacillus keratinases, Keratin substrate, optimization

\section{INTRODUCTION}

Proteases have often been reported to make up a useful class of enzymes with potential applications industrially. Estimates show that these enzymes are responsible for nearly sixty percent of global industrial market due to their large application potential in different industrial processes [1]. They are distributed widely in nature and play a vital role in life processes. They are specifically important for their capacity to hydrolyze peptide bonds in aqueous conditions and to synthesize peptide bonds in non-aqueous biocatalysis [2]. Microbial proteases have been reported to possess certain merits over proteases obtained from plants or animals when considering biochemically-based processes. This is specifically due to their possession of all the qualities required for biotechnological processes [2]. One of such efficient proteases is keratinase.

Keratinases are proteolytic enzymes that are able to catalyse the hydrolysis of highly stable keratin proteins [3]. They are serine metalloproteases which have the capability to liberate the free amino acids from keratinous proteins [4]. Keratinases with microbial origin are mainly extracellular in nature, although intracellular microbial keratinases [5] and few that are cell-bound have been reported [6].

World-wide poultry processing plants produce millions of tons of feathers as a waste product annually which consists of approximately $90 \%$ keratin; the keratin is largely responsible for their high degree of recalcitrance [7], this abundantly available biomass is rich in nitrogen content and is a potential source of fertilizer nutrients [8].

Keratinases could play a vital role in biotechnological applications such as enzymatic conversion of feathers to feather meal [9] and production of amino acids or peptides from high-molecular weight substrates [10] or in clearing obstructions in the sewage system during waste water treatment and eco-friendly de-hairing process in leather industry [11]. This potential can be consolidated by their broad substrate range, their activity rates towards keratin-containing substrates, and their optimal properties for effective hydrolysis of specific substrates. Hence, this study is aimed at the optimal production, purification and characterisation of keratinases from already isolated keratin-degrading Bacillus species.

\section{METHODS}

A. Chemicals

All chemicals used were of analytical grade and were used as obtained from Sigma-Aldrich corporation (https://www.google.com/search?client=opera\&biw=1366\&bi 


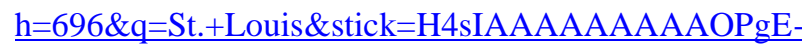
LUz9U3sLC0SK5U4gAxzcoryrW0spOt9POL0hPzMqsSSzLz 81A4VhmpiSmFpYlFJalFxQDMHhGVQwAAAA\&sa=X\&sq $\mathrm{i}=2$ \&ved=0ahUKEwirj77eiMnRAhXCCsAKHcMBBhwQmx MIkwEoATAVSt Louis Missouri, United States). Nutrient Agar was obtained from Central Drug House Limited (New Delhi, India). White chicken feather was obtained locally from a poultry processing factory. The feathers were thoroughly washed with clean water, dried in the oven at $40{ }^{\circ} \mathrm{C}$ for $24 \mathrm{~h}$ and milled to powder.

\section{B. Microorganisms and growth medium}

Bacillus licheniformis-K51, Bacillus subtilis-K50 and Bacillus sp.-K53 were grown in feather broth growth medium as compounded by a modified method [12], which contained, per liter, $\mathrm{NaCl}(0.5 \mathrm{~g}) ; \mathrm{K}_{2} \mathrm{HPO}_{4}(0.3 \mathrm{~g}) ; \mathrm{KH}_{2} \mathrm{PO}_{4}(0.4 \mathrm{~g})$, Yeast extract $(5 \mathrm{~g})$ and feather $(10 \mathrm{~g}), \mathrm{pH} 7.2$.

\section{Preparation of soluble keratin}

Keratinase activity was assayed using soluble keratin substrate $(0.5 \% \mathrm{~g} / \mathrm{v})$ as substrate and was prepared by a modified method [13]. Ten grams of white chicken feathers was heated in $500 \mathrm{~mL}$ of dimethyl sulfoxide (DMSO) at a temperature of $100{ }^{\circ} \mathrm{C}$ for two hours. The resulting soluble keratin was obtained by precipitation with $1 \mathrm{~L}$ acetone at freezing temperature for $6 \mathrm{~h}$. The precipitate was obtained by undergoing centrifugation at $10,000 \mathrm{x} \mathrm{g}$ for $10 \mathrm{~min}$. The resulting precipitate was washed three times with water and dried at $70{ }^{\circ} \mathrm{C}$ for $24 \mathrm{~h}$ in an oven dryer. One gram of the obtained precipitate was dissolved in $20 \mathrm{~mL}$ of $0.05 \mathrm{~mol} / \mathrm{L}$ $\mathrm{NaOH}$. Using $0.1 \mathrm{~mol} / \mathrm{L}$ Tris and $0.1 \mathrm{~mol} / \mathrm{L} \mathrm{HCl}$ the $\mathrm{pH}$ was adjusted and stabilized at 8.0 and the solution was made up to $200 \mathrm{~mL}$ with the same buffer.

\section{Crude keratinase extract preparation}

Bacteria were cultured in $500 \mathrm{ml}$ conical flask containing $100 \mathrm{~mL}$ of the feather broth culture medium that was maintained at $30{ }^{\circ} \mathrm{C}$ and $160 \mathrm{rpm}$ for $96 \mathrm{~h}$. The cells were obtained after cold centrifugation at a speed of $10,000 \mathrm{xg}$, at 4 ${ }^{\circ} \mathrm{C}$ for $10 \mathrm{~min}$. The supernatant, free of bacterial cells were collected and utilized as the crude enzyme preparation.

\section{E. Determination of keratinolytic activity}

The keratinolytic activity of the bacterial enzyme was assayed as follows: One milliliter of the crude enzyme which has been properly diluted in Tris- $\mathrm{HCl}$ buffer $(0.05 \mathrm{~mol} / \mathrm{L}, \mathrm{pH}$ 8.0) was incubated with $1 \mathrm{~mL}$ keratin solution at a temperature of $50{ }^{\circ} \mathrm{C}$ for ten minutes in a water bath. The reaction was terminated by the addition of $2.0 \mathrm{~mL}$ of $0.4 \mathrm{~mol} / \mathrm{L}$ Trichloroacetic acid (TCA). After centrifugation at a speed of $1450 \mathrm{xg}$ for $30 \mathrm{~min}$, the absorbance of the supernatant was determined at a wave length of $280 \mathrm{~nm}$ against a control which was prepared by incubating the enzyme solution with $2.0 \mathrm{~mL}$ TCA without the addition of keratin solution.

One unit $(\mathrm{U} / \mathrm{ml})$ of keratinolytic activity was defined as an increase in corrected absorbance of $280 \mathrm{~nm}\left(\mathrm{~A}_{280}\right)$ [14] with the control for 0.01 per minute and calculated by the following equation:

$$
\mathrm{U}=\frac{4 \mathrm{n} \times \mathrm{A}_{280}}{(0.01 \times 10)}
$$

Where; $\mathrm{n}=$ dilution rate, $4=$ final reaction volume $(4 \mathrm{~mL})$, $10=$ incubation time in minutes

\section{F. Protein estimation}

The concentration of soluble proteins was determined using the technique as described by Lowry [15]. Reagent A consists of $2 \mathrm{~g}$ anhydrous $\mathrm{Na}_{2} \mathrm{CO}_{3}$ and $100 \mathrm{~mL} 0.1 \mathrm{~N} \mathrm{NaOH}$. Reagent $\mathrm{B}$ consists of $1 \mathrm{~g}$ of $1 \% \mathrm{Na}_{4} \mathrm{H}_{4} \mathrm{O}_{6} \mathrm{Na}_{2}, 100 \mathrm{~mL} \mathrm{dH} \mathrm{H}_{2} \mathrm{O}$ and $0.25 \mathrm{~g}$ $\mathrm{CuSO}_{4}$. Reagent $\mathrm{C}$ consists of $50 \mathrm{~mL}$ reagent $\mathrm{A}$ and $1 \mathrm{~mL}$ reagent $\mathrm{B}$.

Three millilitres of reagent $\mathrm{C}$ was added to $0.1 \mathrm{~mL}$ of the extracted enzyme. After which about $0.3 \mathrm{~mL}$ of FolinCiocalteu's reagent was added. This mixture was mixed and incubated at a temperature of $28{ }^{\circ} \mathrm{C}$ for thirty minutes and the optical density of the resulting solution was obtained spectrophotometrically at $660 \mathrm{~nm}$. After which the concentration of the protein in the solution was extrapolated from the Bovine Serum Albumen standard.

\section{G. Optimization of keratinase production}

\section{1) Effect of $p H$ on keratinase production}

The effect of $\mathrm{pH}$ on keratinase production was carried out by a modified method [16]. Eighteen to twenty-four-hour old cultures of the isolates were inoculated in $20 \mathrm{~mL}$ feather medium contained in $100 \mathrm{~mL}$ Erlenmeyer. The $\mathrm{pH}$ of the feather medium was adjusted to $\mathrm{pH} 6.8,7.2,7.5,7.8$ and 8.0 using phosphate buffer. The cell-free supernatant was analyzed for keratinase activity.

2) Effect of incubation temperature on keratinase production

The effect of incubation temperature on keratinase production was carried out by a modified method [16]. Eighteen to twenty-four-hour old cultures of the isolates were inoculated in $20 \mathrm{~mL}$ feather medium contained in $100 \mathrm{~mL}$ Erlenmeyer flasks and were each incubated at $28{ }^{\circ} \mathrm{C}, 32{ }^{\circ} \mathrm{C}, 35$ ${ }^{\circ} \mathrm{C}, 37{ }^{\circ} \mathrm{C}$ and $40{ }^{\circ} \mathrm{C}$ at optimum incubation time, $\mathrm{pH}$ and agitation rate for keratinase production specific for each isolate as determined above. The cell-free supernatant was analyzed for keratinase activity.

\section{3) Effect of Agitation Rate on Keratinase Production}

A modified method [16] was used to determine the effect of agitation rate on keratinase production. The determination of effect of agitation rate was carried out under optimum incubation time and $\mathrm{pH}$ for each isolate as determined from above. Eighteen to twenty-four-hour old cultures of the isolates were inoculated in $20 \mathrm{~mL}$ feather medium contained in $100 \mathrm{~mL}$ Erlenmeyer flasks and were incubated at $37{ }^{\circ} \mathrm{C}$ in a temperature-regulated rotary shaker at agitation rates of 100 rpm, $150 \mathrm{rpm}, 200 \mathrm{rpm}$ and $250 \mathrm{rpm}$ for each isolate. The cellfree supernatant was analyzed for keratinase activity.

4) Effect of different carbon supplements on keratinase production

The effect of various carbon sources on keratinase production was carried out by supplementing the feather medium with $1 \%(\mathrm{~g} / \mathrm{v})$ concentration of various carbon sources: The carbon sources include Mannose, Glucose, Arabinose, Cellulose and Fructose. Each bacterium was inoculated in $20 \mathrm{~mL}$ feather medium (with a carbon supplement) contained in $100 \mathrm{~mL}$ Erlenmeyer flasks and were incubated at optimum cultivation conditions for keratinase production. The cell-free supernatant was analyzed for keratinase activity. The concentration of the carbon supplement that yielded highest keratinase production was varied from $0.2 \%$ to $1.8 \%$ at intervals of 0.4 to optimize enzyme production [17]. 


\section{5) Effect of different nitrogen supplements on keratinase} production

The feather medium was supplemented with $0.2 \%(\mathrm{~g} / \mathrm{v})$ concentration of the following Nitrogen sources: $\left(\mathrm{NH}_{4}\right)_{2} \mathrm{SO}_{4}$, $\mathrm{NaNO}_{3}$, Peptone, $\mathrm{KNO}_{3}$, and $\mathrm{NH}_{4} \mathrm{Cl}$. Each bacterium was inoculated in $20 \mathrm{~mL}$ feather medium (with a Nitrogen supplement) contained in $100 \mathrm{~mL}$ Erlenmeyer flasks and were incubated at optimum cultivation conditions for keratinase production. The cell-free supernatant was analyzed for keratinase activity. The concentration of the Nitrogen supplement that yields highest keratinase production was varied from $0.05 \%$ to $0.40 \%$ to optimize enzyme production [17].

6) Effect of the combination of nitrogen and carbon supplements on keratinase production

Feather medium was supplemented with concentrations of carbon and Nitrogen source that gave optimum enzyme production for each bacterium. Each bacterium was inoculated in $20 \mathrm{~mL}$ feather medium (with carbon and Nitrogen supplement) contained in $100 \mathrm{~mL}$ Erlenmeyer flasks and were incubated under optimum cultivation conditions for keratinase production. The cell-free supernatant was analysed for keratinolytic activity [17].

\section{7) Effect of incubation time on keratinase production}

The effect of incubation time on keratinase production was carried out by a modified method [16]. Eighteen to twenty-four hour old cultures of the isolates were inoculated in $20 \mathrm{~mL}$ feather medium contained in $100 \mathrm{~mL}$ Erlenmeyer flasks and were incubated at $37^{\circ} \mathrm{C}$ at $150 \mathrm{rpm}$ for $24 \mathrm{~h}$. This was repeated for each isolate at incubation time intervals of $24 \mathrm{~h}$ for up to 7 days. The cell-free supernatant was analyzed for keratinase activity.

\section{H. Keratinase purification}

The purification protocol used for the purification of the keratinase enzymes were conducted at temperatures not exceeding $4{ }^{\circ} \mathrm{C}$. Precipitation using ammonium sulfate was carried out on the cell-free supernatant (crude enzyme). The crude enzyme underwent precipitation with $0-30 \%, 30-60 \%$ and $60-90 \%$ ammonium sulphate [18]. The resulting precipitate was obtained by cold centrifugation at 10,000 for $10 \mathrm{~min}$ followed by filtration and dissolution in small volume (1/50) of $10 \mathrm{mM}$ Tris-HCl buffer ( $\mathrm{pH}$ 8.0). Ten milliliters of the dissolved precipitate obtained from the ammonium sulphate precipitation was placed in the dialysis tubing and dialysed against 1 litre $10 \mathrm{mM}$ Tris- $\mathrm{HCl}$ buffer in a beaker. Dialysis was allowed to proceed overnight.

Further purification was achieved using Sephadex G-100 and G-75. The column (2.5 $\mathrm{cm}$ by $70 \mathrm{~cm}$ internal dimension) was each prepared using a modified method of Hames [19]. Two millilitres of the dialysed enzyme concentrate were applied to the column and eluted with buffer to which $5 \mathrm{mM}$ $\mathrm{NaN}_{3}$ was added. Five (5) millilitres of the fractions were collected per tube. The keratinase activity of each fraction was determined as described earlier and fractions showing appreciable keratinase activity were pooled together.

1) Determination of Molecular weight of keratinase using Sodium Dodecyl Sulphate-Polyacrylamide Gel Electrophoresis (SDS-PAGE)

Sephadex G-75 column chromatography fractions showing enzymatic activity were pooled, lyophilized and then subjected to SDS-PAGE. It was performed according to a modified method [20] using 30\% acrylamide.

Materials used for this procedure included a resolving gel mix consisting of $30 \%$ Acrylamide $+1.5 \%$ Bisacrylamide, $0.28 \%$ (v/v) Tetra-Methylethylenediamine (TEMED), $10 \%$ Ammonium persulfate (w/v), distilled water, Tris-HCl buffer (2 $\mathrm{M} \mathrm{pH} \mathrm{8.0),} \mathrm{and} \mathrm{10 \%} \mathrm{sodium} \mathrm{dodecyl} \mathrm{sulphate} \mathrm{(SDS).}$

The resolving gel was prepared by the dissolution of the following components in sequence, $30 \%$ Acrylamide $+1.5 \%$ Bisacrylamide followed by TEMED, the running buffer and lastly ammonium persulfate which acts as a catalyst. After the complete dissolution of all the components, $0.25 \mathrm{~mL}$ of SDS was then added with thorough mixing and the entire mixture was allowed to polymerise for about $20 \mathrm{~min}$. Stacking gel was prepared by mixing the following in sequence; $2 \mathrm{~mL}$ Acrylamide followed by $0.2 \mathrm{~mL}$ of $10 \%$ SDS, $0.01 \mathrm{~mL}$ TEMED, $0.2 \mathrm{~mL}$ Ammonium persulfate and lastly small crystals of Bromophenol blue.

In filling and running of the vertical gel apparatus, the two glass plates meant to support the gel were initially clamped together with silicon gaskets to prevent the gel mixture from leaking out before polymerization followed by the pipetting of the resolving gel using a Pasteur pipette between the clamped plates to fill to about $3.8 \mathrm{~cm}$ from the top. Distilled water saturated with 2-butanol was layered on the gel surface using a Pasteur pipette to ensure an even surface and to avoid evaporation of the gel while the gel was allowed to polymerize for 1-2 h. After initial polymerization, the water on the gel was poured off and the Stacking gel layered over the initial Resolving gel gently followed by insertion of the well comb and then more of the stacking gel was poured until the glass plates overflowed. This second layer of gel was allowed to polymerize after which the comb was removed. Next, the sealing gaskets were removed, and the slabs were placed into the electrophoretic apparatus. The buffer reservoirs were filled with the running buffer- 0.05 phosphate buffer +0.2g SDS + $48 \mathrm{~g}$ Urea $+0.2 \mathrm{~mL} 2$-mercaptoethanol $\mathrm{pH}$ 7.0. After this, a Gilson pipette was used to apply the samples to the wells; one sample per well while standard markers were applied to adjoining well.

The electrophoretic kit was then connected to the power source with constant supply of electricity until the samples have run into the gel. Keeping the current down to $20 \mathrm{~mA}$ at first then increased to $40 \mathrm{~mA}$ about half way into the electrophoretic process. The power was turned off as the bromophenol blue band was approaching the bottom of the gel.

At the end of the electrophoresis, the power source was switched off and the glass plates were gently separated, and the gel eased into a small tray containing Coomassie Blues R-250, $50 \%(\mathrm{w} / \mathrm{v})$ methanol and $7.5 \%$ acetic acid and then de-stained in in $7.5 \%$ acetic acid and $30 \%$ methanol. The tray was constantly agitated until the bands become apparent when viewed over a light box. Excess stain was removed by immersing the gel for 1 hour in several changes of the destaining solution each lasting for 15-20 minutes. The gel was then removed and allowed to solidify.

The standard protein samples that were utilized were obtained by mixing sample buffer (in a dilution of $1: 1 \mathrm{v} / \mathrm{v}$ ) with the enzymes. The mixture was then placed in a dry bath and heated for 4 minutes at $95^{\circ} \mathrm{C}$. Equal volume of sample was applied to the bottom of the sample wells with a Gilson pipette. 


\section{Characterisation of keratinase}

1) Amino acid profiling of keratinase enzyme

The keratinase sample was diluted and incubated in $1 \mathrm{M}$ $\mathrm{KOH}$ solution for two days at a temperature of $110{ }^{\circ} \mathrm{C}$ in hermetically closed borosilicate glass container. After the alkaline hydrolysis, the hydrolysate was neutralized to get $\mathrm{pH}$ in the range of 2.5-5.0. The solution was purified by cationexchange solid phase extraction. The amino acid in purified solution was derivatized by ethylchloroformate. The derivatization reagent removed by scavenge with nitrogen gas for proper mop up of the excess reagent. The derivatized amino acid that is free of derivatizing reagent was made up to $1 \mathrm{~mL}$ in a vial for gas chromatography in a Gas chromatograph (HP 6890 powered with HP Chem Station Rev. A 09.01 [1206] software) under the following conditions: Analytical column $10 \mathrm{~m}$ x $0.25 \mathrm{~mm} \mathrm{EZ}$ : Faast; temperature program of analytical column $-0.3 \mathrm{~min}$. at $110^{\circ} \mathrm{C}, 27^{\circ} \mathrm{C} / \mathrm{min}$. from $110^{\circ} \mathrm{C}$ to $320^{\circ} \mathrm{C}$, $5 \mathrm{~min}$. at $320{ }^{\circ} \mathrm{C}$; temperature of injector (split - splittless in split regime) $-250{ }^{\circ} \mathrm{C}$; temperature of flame - ionization detector $-320{ }^{\circ} \mathrm{C}$.

2) Effect of temperature on keratinase activity of crude and purified enzyme

The effect of temperature on the activity of the crude and purified keratinase produced by the isolates was determined by incubating the keratinase with the substrate preparation at different temperatures $\left(30{ }^{\circ} \mathrm{C}, 40{ }^{\circ} \mathrm{C}, 50{ }^{\circ} \mathrm{C}, 60{ }^{\circ} \mathrm{C}, 70{ }^{\circ} \mathrm{C}\right.$ and $80{ }^{\circ} \mathrm{C}$ ) enzyme activity was assayed as previously described.

3) Effect of $\mathrm{pH}$ on keratinase activity of crude and Purified enzyme

The effect of the activity of the crude and purified keratinase produced by the isolates was determined by incubating the keratinase with the substrate preparation at different $\mathrm{pH}(7,8,9,10,11,12,13)$ using $0.1 \mathrm{M}$ phosphate buffer [16]. The activity of the enzyme was determined as previously described.

4) Effect of metal ions on keratinase Activity

The effect of metal ions on crude and purified Keratinases was investigated by reacting $0.1 \mathrm{~mL}$ enzyme solution with 0.9 $\mathrm{mL}$ of keratin containing $10 \mathrm{mM}$ of $\mathrm{Ca}^{2+}, \mathrm{Mg}^{2+}, \mathrm{Fe}^{2+}, \mathrm{Mn}^{2+}$, $\mathrm{Hg}^{2+}$ and $\mathrm{Cu}^{2+}[21]$. The activity of the enzyme was measured as previously described.

5) Effect of substrate concentration on keratinase activity

The effect of substrate concentration on keratinase activity was done using the method of [22]. Different concentrations ( $2 \%$ up to $12 \%$ with intervals of $2 \%(\mathrm{~g} / \mathrm{v})$ ) of keratin were separately prepared in 0.2 Tris- $\mathrm{HCl}$ buffer ( $\mathrm{pH} 7$ ). Keratinase assay was done using the different substrate concentrations.

\section{6) Kinetic studies}

The kinetic constants $\mathrm{K}_{\mathrm{M}}$ and $\mathrm{V}_{\max }$ values using keratin as substrate were evaluated by fitting the experimental data to the Michaelis-Menten model using GraphPad Prism version 7.04 for Windows, GraphPAd software, San Diego California USA, www.graphpad.com.

\section{J. Statistical analysis}

The data obtained from this experiment were analyzed by one way analysis of variance (ANOVA) and means of differences among treatment were examined using Duncan's multiple rage test at $\mathrm{p} \pm 0.05$.

\section{RESULT}

\section{A. Effect of $p H$ on keratinase production}

The Effect of $\mathrm{pH}$ on keratinase production is shown in figure 1 For Bacillus subtilis-K50, highest keratinolytic activity of $17.87 \pm 0.89 \mathrm{U} / \mathrm{mL}$ was recorded at $\mathrm{pH} 7.5$. As $\mathrm{pH}$ increased from 6.8 to 7.2 enzyme activity increased sharply from $1.58 \pm 0.72 \mathrm{U} / \mathrm{mL}$ to $16.71 \pm 0.64 \mathrm{U} / \mathrm{mL}$. Keratinase activity increased gradually to $17.87 \pm 0.89 \mathrm{U} / \mathrm{mL}$ as $\mathrm{pH}$ increases from 7.2 to 7.5. This was followed by a gradual decrease in activity at $\mathrm{pH} 7.8$ and subsequently a decline at $\mathrm{pH}$ 8.0. Highest enzyme activity $(23.78 \pm 0.40 \mathrm{U} / \mathrm{mL})$ was recorded for Bacillus licheniformis-K51 at $\mathrm{pH}$ 7.8. Keratinase activity is shown to increase from $\mathrm{pH} 6.8$ to $\mathrm{pH}$ 7.2. No observable increase in activity is shown at $\mathrm{pH} 7.5$. A gradual increase and subsequent reduction in activity is shown at $\mathrm{pH} 7.8$ and 8.0 respectively. Highest enzyme activity for Bacillus sp.-K53 (18.41 \pm 0.60 $\mathrm{U} / \mathrm{mL}$ ) was recorded at $\mathrm{pH}$ 7.2. The result shows increase in enzyme activity as $\mathrm{pH}$ increased from $\mathrm{pH} 6.8$ to $\mathrm{pH} 7.2$ and subsequently, a gradual reduction in activity as $\mathrm{pH}$ increased further to 8.0.

\section{B. Effect of incubation temperature on keratinase production}

The result for the effect of different incubation temperatures on keratinase production for Bacillus subtilisK50, Bacillus licheniformis-K51 and Bacillus sp.-K53 (Figure 2) revealed that all the isolates showed maximum keratinase production at incubation temperature of $37^{\circ} \mathrm{C}$ with activities of $23.78 \pm 0.40 \mathrm{U} / \mathrm{mL}, 18.12 \pm 1.05 \mathrm{U} / \mathrm{mL}$ and $18.41 \pm 0.60 \mathrm{U} / \mathrm{mL}$ for Bacillus licheniformis-K51, Bacillus subtilis-K50 and Bacillus sp.-K53 respectively. Bacillus subtilis-K50 and Bacillus sp.K53 showed gradual increase in enzyme activities as the incubation temperature increased from $28^{\circ} \mathrm{C}$ to $37{ }^{\circ} \mathrm{C}$ after which there was a decline with further increase in temperature from $37{ }^{\circ} \mathrm{C}$ to $40{ }^{\circ} \mathrm{C}$. For Bacillus licheniformis-K51, enzyme production was observed to increase with increase in incubation temperature from $28{ }^{\circ} \mathrm{C}$ to $32^{\circ} \mathrm{C}$, activity remained constant as the temperature increased further to $35^{\circ} \mathrm{C}$, this was followed by a gradual increase in activity and subsequent, a gradual decline as the temperature increased further from $35^{\circ} \mathrm{C}$ to $37{ }^{\circ} \mathrm{C}$ and from $37{ }^{\circ} \mathrm{C}$ to $40{ }^{\circ} \mathrm{C}$ respectively

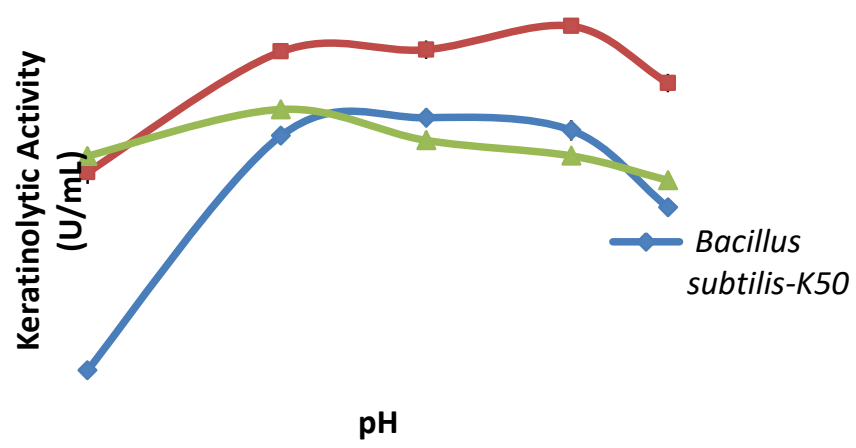

Figure 1. Effect of $\mathbf{p H}$ on keratinase production by Bacillus spp. 


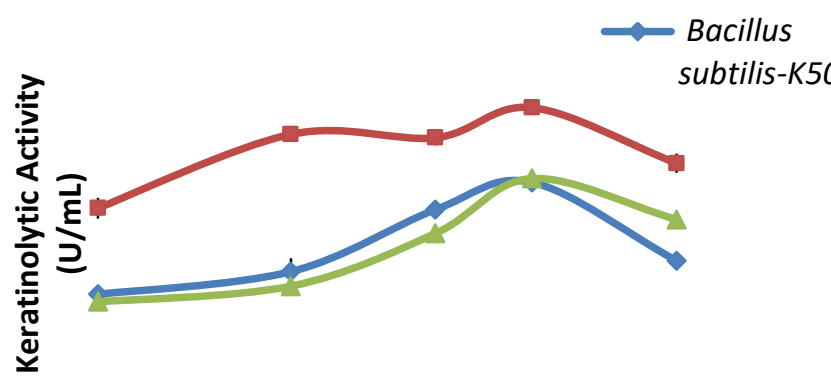

Temperature $\left({ }^{\circ} \mathrm{C}\right)$

Figure 2. Effect of incubation temperature on keratinase production by Bacillus spp.

\section{Effect of agitation rate on keratinase production}

The effect of agitation rate on keratinase production by the three keratinase-producing bacteria is shown in figure 3 . It is observed that Bacillus subtilis-K50 and Bacillus sp.-K53 gave optimum keratinase production at agitation rate of $150 \mathrm{rpm}$ while Bacillus subtilis-K50 gave optimum agitation rate of 200 rpm, with Bacillus subtilis-K50 having highest activity of $23.78 \pm 0.40 \mathrm{U} / \mathrm{mL}$ followed by Bacillus sp.-K53 (18.41 \pm 0.60 $\mathrm{U} / \mathrm{mL})$ and then Bacillus subtilis-K50 $(18.12 \pm 1.05 \mathrm{U} / \mathrm{mL})$. Bacillus subtilis-K50 showed a gradual increase in keratinase activity as agitation rate increased from $100 \mathrm{rpm}$ to $200 \mathrm{rpm}$ followed by a gradual decline with further increase in agitation rate to $250 \mathrm{rpm}$. Increase in enzyme activity was observed with increase in agitation rate from $100 \mathrm{rpm}$ to $150 \mathrm{rpm}$ for Bacillus subtilis-K50 and Bacillus sp.-K53, this was followed by a reduction in activity with further increase from $150 \mathrm{rpm}$ to 250 rpm.

\section{Effect of different carbon sources on keratinase production by isolates}

The effect of different carbon sources on keratinase production by the three bacteria isolates is as shown in figure 4 . Among the different carbon supplements (mannose, glucose, arabinose, cellulose and fructose), keratinase production was highest with cellulose for Bacillus licheniformis-K51, Bacillus subtilis-K50 and Bacillus sp.-K53 with keratinolytic activities of $22.15 \mathrm{U} / \mathrm{mL}, 18.25 \mathrm{U} / \mathrm{mL}$ and $15.30 \mathrm{U} / \mathrm{mL}$ respectively. Glucose supplements in the culture medium produced lowest keratinase activity with Bacillus licheniformis-K51 (13.05 $\mathrm{U} / \mathrm{mL})$ and Bacillus sp.-K53 (6.80 U/mL) while enzyme activity was lowest $(10.51 \mathrm{U} / \mathrm{mL})$ with Bacillus subtilis-K50 in the presence of Arabinose.

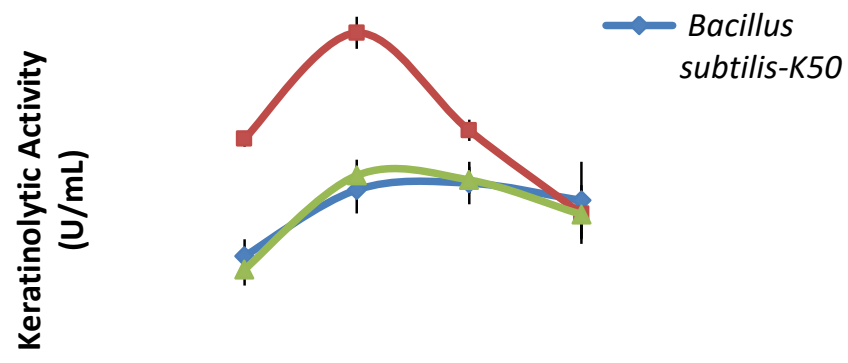

Agitation rate
Figure 3. Effect of agitation rate on keratinase production by Bacillus spp.

Bacillus subtilis-K50
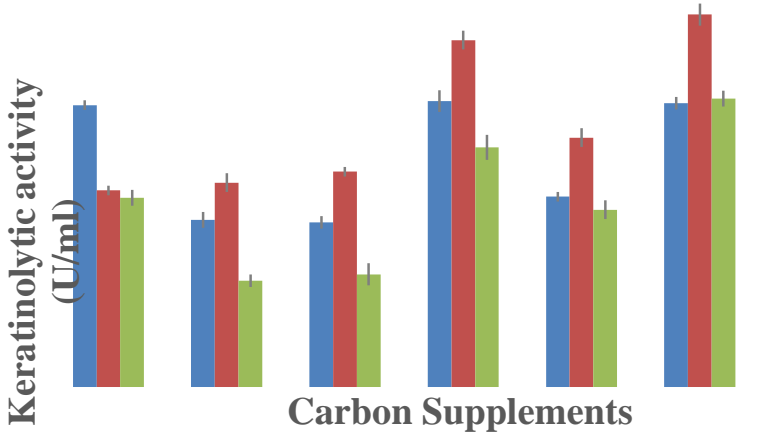

Figure 4: Effect of Different Carbon Source (Supplement with chicken feather) on keratinase production by Bacillus spp.

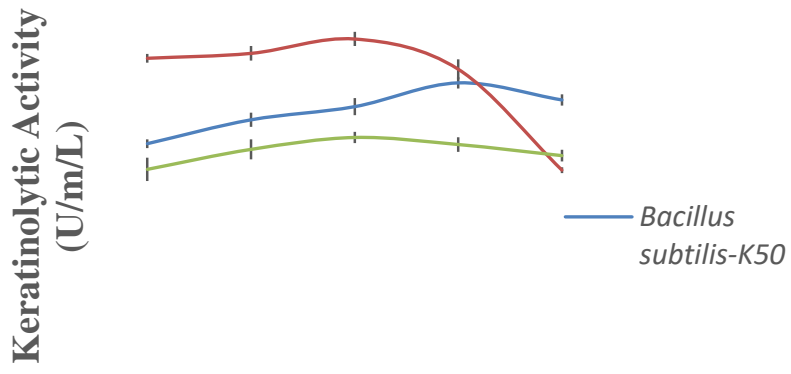

Cellulose Concentration (\%)

Figure 5. Effect of different cellulose concentrations on keratinase production by isolates

The effect of cellulose concentration on keratinase production by the three selected isolates is shown in figure 5 . The effect of varying the concentration of cellulose in the growth medium $(0.2 \%, 0.6 \%, 1.0 \%, 1.4 \%$ and $1.8 \%)$ showed increase in enzyme activity for Bacillus subtilis-K50 as cellulose concentration increased from $0.2 \%$ to $1.4 \%$. Enzyme activity remained highest $(19.10 \mathrm{U} / \mathrm{mL})$ at $1.4 \%$ cellulose concentration after which there was a decline with further increase in cellulose concentration. For Bacillus licheniformisK51 and Bacillus sp.-K53, keratinase activity increased with increased cellulose concentration from $0.2 \%$ to $1.0 \%$. Keratinase production remained highest for Bacillus licheniformis-K51 (22.15 U/mL) and Bacillus sp.-K53 (15.30 $\mathrm{U} / \mathrm{mL}$ ) at $1.0 \%$ cellulose concentration, while further increase from $1.0 \%$ resulted in reduced keratinase production.

\section{E. Effect of different nitrogen sources on keratinase production by isolates}

Figure 6 shows the effect of different nitrogen supplements in the fermentation medium on keratinase production by the three bacteria. Of the five nitrogen supplements, $\left(\mathrm{NH}_{4}\right)_{2} \mathrm{SO}_{4}$ gave highest enzyme activities $(14.90 \mathrm{U} / \mathrm{mL}, 24.15 \mathrm{U} / \mathrm{mL}$ and $13.85 \mathrm{U} / \mathrm{mL}$ ) and $\mathrm{NH}_{4} \mathrm{Cl}$ gave the least enzyme activity of $10.04 \mathrm{U} / \mathrm{mL}, 12.13 \mathrm{U} / \mathrm{mL}$ and $10.06 \mathrm{U} / \mathrm{mL}$ for Bacillus subtilis-K50, Bacillus licheniformis-K51 and Bacillus sp.-K53 respectively. Except for Bacillus licheniformis-K51 which 
showed higher keratinase activity $(24.15 \mathrm{U} / \mathrm{mL})$ in the presence of $\left(\mathrm{NH}_{4}\right)_{2} \mathrm{SO}_{4}$ compared with the activity $(23.78 \mathrm{U} / \mathrm{mL})$ of the control, the activities of the enzymes for the other bacteria isolates in the control medium (without nitrogen supplement) was higher compared to enzyme activities with any of the nitrogen supplements.

The effect of different $\left(\mathrm{NH}_{4}\right)_{2} \mathrm{SO}_{4}$ concentrations on keratinase production by the isolates is shown in figure 7 . Generally, enzyme activities were highest with Bacillus licheniformis-K51 and least for Bacillus sp.-K53 at all concentrations of $\left(\mathrm{NH}_{4}\right)_{2} \mathrm{SO}_{4}$. For Bacillus subtilis-K50, increase in concentration of $\left(\mathrm{NH}_{4}\right)_{2} \mathrm{SO}_{4}$ from $0.05 \%$ to $0.1 \%$ resulted in an increase in enzyme activity. This was followed by a reduction in activity as $\left(\mathrm{NH}_{4}\right)_{2} \mathrm{SO}_{4}$ concentration increased further to $0.2 \%$. Further increase in $\left(\mathrm{NH}_{4}\right)_{2} \mathrm{SO}_{4}$ concentration from $0.2 \%$ to $0.3 \%$ resulted in a sharp increase in enzyme activity from $14.90 \mathrm{U} / \mathrm{mL}$ to $16.78 \mathrm{U} / \mathrm{mL}$. The enzyme activity remained highest at $0.3 \% \quad\left(\mathrm{NH}_{4}\right)_{2} \mathrm{SO}_{4}$ concentration and dropped abruptly to $10.12 \mathrm{U} / \mathrm{mL}$ as $\left(\mathrm{NH}_{4}\right)_{2} \mathrm{SO}_{4}$ concentration increased further to $0.4 \%$. Keratinase activity for Bacillus licheniformis-K51 and Bacillus sp.-K53 was noted to increase as $\left(\mathrm{NH}_{4}\right)_{2} \mathrm{SO}_{4}$ concentration increased from $0.05 \%$ to $0.3 \%$. Keratinase activities also remained highest for Bacillus licheniformis-K51 and Bacillus sp.-K53 at $0.3 \%\left(\mathrm{NH}_{4}\right)_{2} \mathrm{SO}_{4}$ concentration while further increase resulted in a reduction in keratinase activity.

\section{$F$. The effect of combining optimum concentrations of nitrogen and carbon sources on keratinase production}

Table 1 shows the result of effect of combining $\left(\mathrm{NH}_{4}\right)_{2} \mathrm{SO}_{4}$ and cellulose at optimum concentrations on keratinase production. For all the three bacteria, $\left(\mathrm{NH}_{4}\right)_{2} \mathrm{SO}_{4}$ and cellulose at optimum concentrations yielded significantly $(\mathrm{P} \leq .05)$ lesser enzyme activity when combined in the medium than when added separately. For Bacillus subtilis-K50, addition of $1.4 \%$ cellulose into the medium resulted in a significantly higher $(\mathrm{P} \leq .05)$ enzyme activity $(19.09 \pm 0.74 \mathrm{U} / \mathrm{mL})$ than the activities when cellulose and $\left(\mathrm{NH}_{4}\right)_{2} \mathrm{SO}_{4}$ supplements were absent (for control) $(16.06 \pm 0.24 \mathrm{U} / \mathrm{mL})$ and present in combined form (14.12 $\pm 0.31 \mathrm{U} / \mathrm{mL})$. For Bacillus licheniformis-K51, addition of $0.3 \%\left(\mathrm{NH}_{4}\right)_{2} \mathrm{SO}_{4}$, into the growth medium resulted in a significantly higher $(\mathrm{P} \leq .05)$ enzyme activity of $24.76 \pm 0.91$ $\mathrm{U} / \mathrm{mL}$ than the activity for control (without carbon or Nitrogen supplements) $(23.78 \pm 0.40 \mathrm{U} / \mathrm{mL})$ and for growth medium with cellulose and $\left(\mathrm{NH}_{4}\right)_{2} \mathrm{SO}_{4}$ combined $(18.31 \pm 0.89 \mathrm{U} / \mathrm{mL})$. For Bacillus sp.-K53, keratinase activity without carbon or Nitrogen supplement in growth medium (control) $(18.40 \pm 0.60$ $\mathrm{U} / \mathrm{mL}$ ) was significantly higher than enzyme activities in the presence of $\left(\mathrm{NH}_{4}\right)_{2} \mathrm{SO}_{4}$ and cellulose supplements separately $(14.20 \pm 0.33 \mathrm{U} / \mathrm{mL}$ and $15.29 \pm 0.84 \mathrm{U} / \mathrm{mL}$ respectively) and in combination $(12.20 \pm 0.50 \mathrm{U} / \mathrm{mL})$

\section{G. Effect of Incubation time on Keratinase Production}

The effect of incubation time on keratinase production is shown in figure 8. Bacillus subtilis-K50 showed highest keratinase activity of $16.71 \pm 0.64 \mathrm{U} / \mathrm{mL}$ on day 4 , Bacillus licheniformis-K51 had highest keratinase activity $(22.13 \pm 0.30$ $\mathrm{U} / \mathrm{mL}$ ) on day 7 of incubation and Bacillus sp.-K53 showed highest enzyme activity of $18.74 \pm 0.61 \mathrm{U} / \mathrm{mL}$ on day 5 of incubation.
From the figure, Bacillus subtilis-K50 showed a sharp increase in enzyme activity with increase in incubation time from day 1 to day 4. A gradual reduction in enzyme activity from day 4 to day 5 was observed, which was followed by a sudden decline from day 5 to day 6. Enzyme activity reduced further with subsequent increase in the number of days. Bacillus licheniformis-K51 showed no observable increase in keratinase activity from day 1 to day 2 of incubation. A gradual increase in enzyme activity was observed from day 2 to day 3 followed by a sharp increase on day 4 , the activity increased steadily from day $4(14.48 \pm 1.25 \mathrm{U} / \mathrm{mL})$ to day $7(22.13 \pm 0.30$ $\mathrm{U} / \mathrm{mL}$ ) which was followed by a decrease on day 8 (19.21 $\pm 1.04 \mathrm{U} / \mathrm{mL})$. Bacillus sp.-K53 also showed no observable increase in keratinase activity on day 1 and day 2 of incubation after which a rapid increase in enzyme activity was observed on days 3 and $4(11.66 \pm 1.28$ and $18.25 \pm 1.09 \mathrm{U} / \mathrm{mL}$ respectively). Activity increased gradually from day 4 to day 5 . Reduction in activity on day $6(18.11 \pm 0.25 \mathrm{U} / \mathrm{mL})$ was also gradual and was followed by a drastic decline on $7(4.64 \pm 1.37$ $\mathrm{U} / \mathrm{mL})$. Enzyme activity $(2.95 \pm 0.87 \mathrm{U} / \mathrm{mL})$ reduced further up till day 8 of incubation.

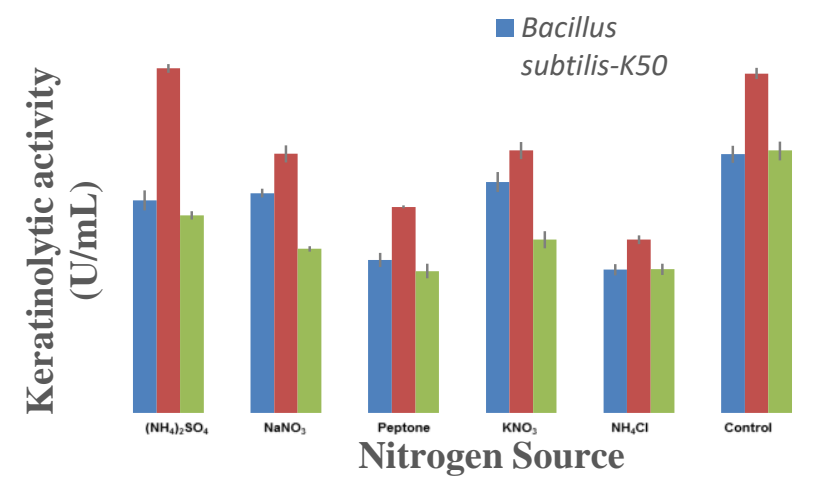

Figure 6. Effect of Different Nitrogen Source (Supplemented with chicken feathers) on Keratinase production by isolates

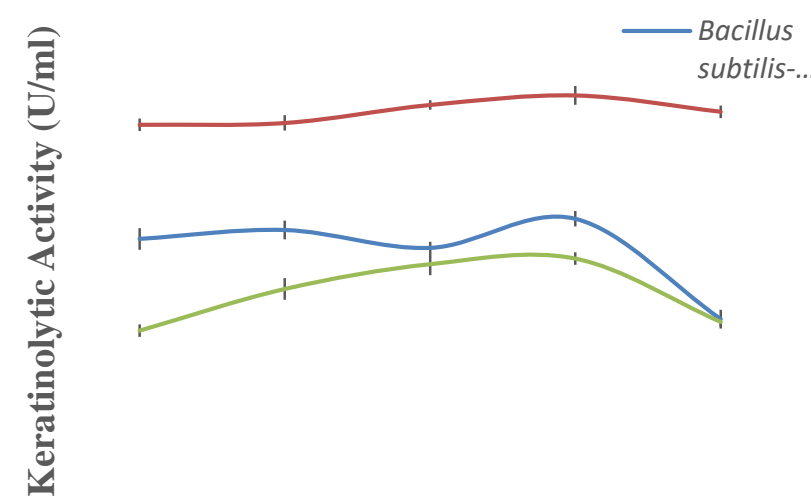

$\left(\mathrm{NH}_{4}\right)_{2} \mathrm{SO}_{4}$ Concentration (\%)

Figure 7. Effect of Different $\left(\mathrm{NH}_{4}\right)_{2} \mathrm{SO}_{4}$ Concentrations on Keratinase Production by isolates 
Table 1. The effect of combining optimum concentrations of $\left(\mathrm{NH}_{4}\right)_{2} \mathrm{SO}_{4}$ and cellulose on keratinase production by isolates

\begin{tabular}{|c|c|c|c|c|}
\hline \multirow[b]{2}{*}{ Isolate } & \multicolumn{4}{|c|}{ Keratinolytic Activity (U/mL) } \\
\hline & $\begin{array}{c}\text { Without Carbon or } \\
\text { Nitrogen Supplement }\end{array}$ & $\begin{array}{l}\text { With } 0.3 \%\left(\mathrm{NH}_{4}\right)_{2} \mathrm{SO}_{4} \\
\text { only }\end{array}$ & $\begin{array}{l}\text { With } 1.4 \% \text { cellulose } \\
\text { only }\end{array}$ & $\begin{array}{l}\text { With } 0.3 \%\left(\mathrm{NH}_{4}\right)_{2} \mathrm{SO}_{4}+ \\
\quad 1.4 \% \text { Cellulose } \\
\end{array}$ \\
\hline \multirow[t]{2}{*}{ Bacillus subtilis-K50 } & $16.06 \pm 0.24^{\mathrm{b}}$ & $16.78 \pm 0.25^{\mathrm{b}}$ & $19.09 \pm 0.74^{\mathrm{c}}$ & $14.12 \pm 0.31^{\mathrm{a}}$ \\
\hline & $\begin{array}{c}\text { Without Carbon or } \\
\text { Nitrogen Supplement }\end{array}$ & $\begin{array}{c}\text { With } 0.3 \%\left(\mathrm{NH}_{4}\right)_{2} \mathrm{SO}_{4} \\
\text { only }\end{array}$ & $\begin{array}{l}\text { With } 1 \% \text { cellulose } \\
\text { only } \\
\end{array}$ & $\begin{array}{c}\text { With } 0.3 \%\left(\mathrm{NH}_{4}\right)_{2} \mathrm{SO}_{4}+1 \% \\
\text { Cellulose }\end{array}$ \\
\hline Bacillus licheniformis-K51 & $23.78 \pm 0.40^{\mathrm{c}}$ & $24.76 \pm 0.91^{\mathrm{d}}$ & $22.14 \pm 0.75^{\mathrm{b}}$ & $18.31 \pm 0.89^{\mathrm{a}}$ \\
\hline Bacillus sp.-K53 & $18.40 \pm 0.60^{\mathrm{d}}$ & $14.20 \pm 0.33^{\mathrm{b}}$ & $15.29 \pm 0.84^{\mathrm{c}}$ & $12.20 \pm 0.50^{\mathrm{a}}$ \\
\hline
\end{tabular}

Values are in means \pm standard deviation; at 95\% confidence level, means with different / similar superscripts along the same row are significantly different / not significantly different from one another 


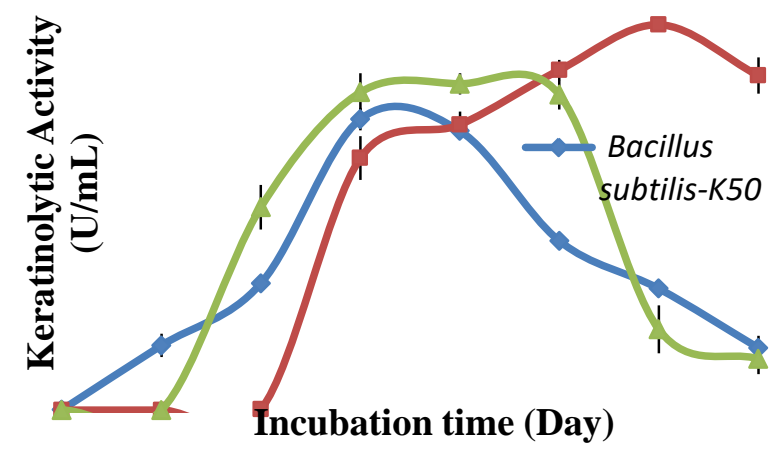

Figure 8. Effect of Incubation time on keratinase production by selected isolates

H. Optimum cultivation conditions for keratinase production by isolates

The optimum cultivation conditions for keratinase production for Bacillus subtilis-K50, Bacillus licheniformisK51 and Bacillus sp.-K53 is as shown in Table 2. Bacillus licheniformis-K51 gave highest keratinase activity of 24.762 $\mathrm{U} / \mathrm{mL}$ at $\mathrm{pH} 7.8,37^{\circ} \mathrm{C}$, agitation rate $150 \mathrm{rpm}$ and $0.3 \%$ $\left(\mathrm{NH}_{4}\right)_{2} \mathrm{SO}_{4}$ on day 7 , while Bacillus subtilis-K50 had $19.03 \pm 0.74 \mathrm{U} / \mathrm{mL}$ at $\mathrm{pH} 7.5,37^{\circ} \mathrm{C}$, agitation rate $200 \mathrm{rpm}$ and $1.4 \%$ cellulose on day 4. Bacillus sp.-K53 gave optimum activity of $18.41 \pm 0.60 \mathrm{U} / \mathrm{mL}$ at $\mathrm{pH} 7.2,37^{\circ} \mathrm{C}$ and agitation rate $150 \mathrm{rpm}$ on day 5 .

\section{Enzyme purification}

The result of the purification of keratinase obtained from Bacillus subtilis-K50, Bacillus licheniformis-K51 and Bacillus sp.-K53 is presented in Table 3. The maximum specific enzyme activity was determined at $183.6 \mathrm{U} / \mathrm{mg}, 190.4 \mathrm{U} / \mathrm{mg}$ and $105.6 \mathrm{U} / \mathrm{mg}$ for keratinase from Bacillus subtilis-K50 (EZYKer-50), Bacillus licheniformis-K51 (EZYKer-51) and Bacillus sp.-K53 (EZYKer-53) respectively enabling respective keratinase purification folds of 15.6, 33.1 and 14folds with yields of $12.1 \%, 20.3 \%$ and $14.1 \%$ respectively. For EZYKer-50, ammonium sulfate precipitation and dialysis of crude enzyme gave respective overall protein yield of $79.8 \%$ and $55.7 \%$ with respective specific activities of 12.2 $\mathrm{U} / \mathrm{mg}$ and $105.5 \mathrm{U} / \mathrm{mg}$ and purification fold of 1.1 and 8.9. Fractionation of the crude supernatant on Sephadex G-100 was purified 8.7 folds with an overall protein yield of $13.5 \%$ and specific activity of $102.6 \mathrm{U} / \mathrm{mg}$, while fractions obtained from Sephadex G-75 resolution gave an overall yield of $12.1 \%$ and specific activity of $183.6 \mathrm{U} / \mathrm{mg}$ and was purified 15.6 folds. For EZYKer-51, ammonium sulfate precipitation and dialysis of crude enzyme gave respective overall protein yield of $70.8 \%$ and $41.0 \%$ with respective specific activities of 7.5 $\mathrm{U} / \mathrm{mg}$ and $10.5 \mathrm{U} / \mathrm{mg}$ and purification fold of 1.3 and 1.8 . Fractionation of the crude supernatant on Sephadex G-100 was purified 3.8 folds with an overall protein yield of $18.6 \%$ and specific activity of $21.2 \mathrm{U} / \mathrm{mg}$, while fractions obtained from Sephadex G-75 resolution gave an overall yield of $20.3 \%$ and specific activity of $190.4 \mathrm{U} / \mathrm{mg}$ and was purified 33.1 folds.

For EZYKer-53, ammonium sulfate precipitation and dialysis of crude enzyme gave respective overall protein yield of $87.9 \%$ and $63.3 \%$ with respective specific activities of 28.1 $\mathrm{U} / \mathrm{mg}$ and $35.3 \mathrm{U} / \mathrm{mg}$ and purification fold of 3.7 and 4.7 . Fractionation of the crude supernatant on Sephadex G-100 was purified 3.7 folds with an overall protein yield of $14.2 \%$ and specific activity of $27.6 \mathrm{U} / \mathrm{mg}$, while fractions obtained from Sephadex G-75 resolution gave an overall yield of $13.1 \%$ and specific activity of $105.6 \mathrm{U} / \mathrm{mg}$ and was purified 14.1 folds.

\section{J. Molecular weight of keratinases}

The result for the SDS-PAGE of the purified EZYKer-50, EZYKer-51 and EZYKer-53 is presented in the electrophoretogram in Figure 9. The result shows single protein bands on lanes 1, 2 and 3 for EZYKer-53, EZYKer-50 and EZYKer-51 respectively. These bands correspond approximately to the standard protein marker (lane 4) having molecular weight of $36 \mathrm{KDa}$

$$
\text { www.scirj.org }
$$


Table 2 Optimum cultivation conditions for keratinase production by isolates

\begin{tabular}{|c|c|c|c|c|c|c|c|}
\hline Isolates & pH & $\begin{array}{l}\text { Incubation } \\
\text { temperature } \\
\left({ }^{\circ} \mathrm{C}\right)\end{array}$ & $\begin{array}{l}\text { Agitation } \\
\text { rate } \\
(\text { rpm })\end{array}$ & $\begin{array}{l}\text { Incubation } \\
\text { time (Days) }\end{array}$ & Nitrogen & Carbon & $\begin{array}{r}\text { Keratinolytic } \\
\text { Activity }(\mathrm{U} / \mathrm{mL})\end{array}$ \\
\hline Bacillus subtilis-K50 & 7.5 & 37 & 200 & 4 & - & $\begin{array}{c}1.4 \% \\
\text { Cellulose }\end{array}$ & $19.02 \pm 0.74$ \\
\hline Bacillus licheniformis-K51 & 7.8 & 37 & 150 & 7 & $\begin{array}{c}0.3 \% \\
\left(\mathrm{NH}_{4}\right)_{2} \mathrm{SO}_{4}\end{array}$ & - & $24.762 \pm 0.91$ \\
\hline
\end{tabular}

- Indicates that the presence of the parameter being tested did not yield keratinolytic activity higher than optimum

\section{Table 3. Purification Profile of Keratinases}

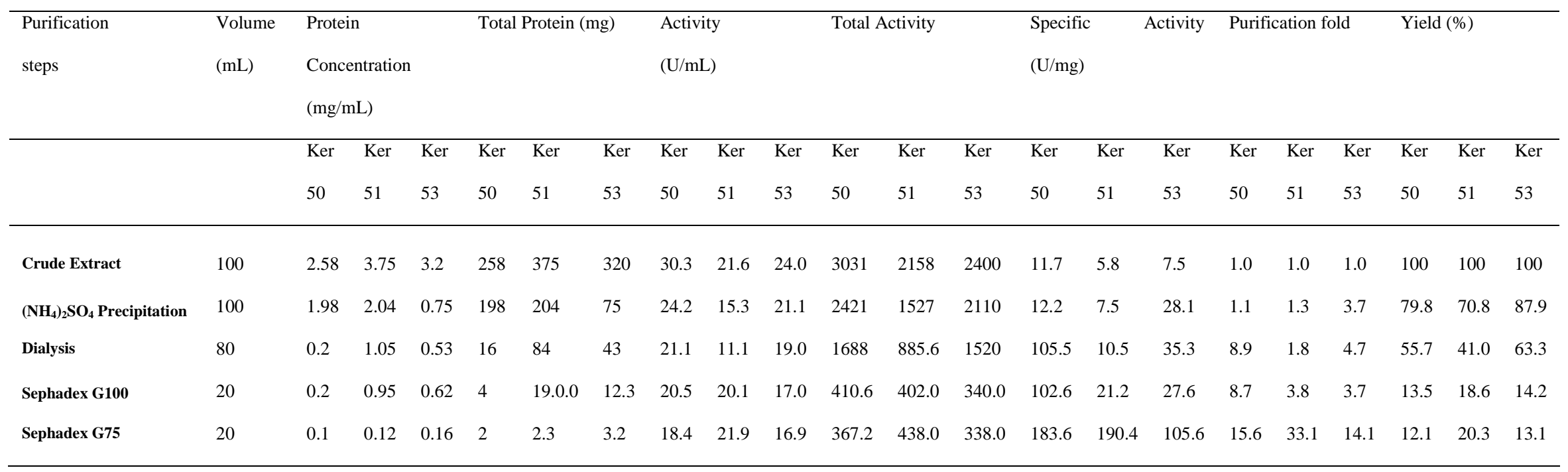

Key:

EZYKer-50- $\quad$ Keratinase obtained from Bacillus subtilis-K50

EZYKer-51- Keratinase obtained from Bacillus licheniformis-K51 
EZYKer-53- Keratinase obtained from Bacillus sp.-K53

www.scirj.org

(C) 2020, Scientific Research Journal

http://dx.doi.org/10.31364/SCIRJ/v8.i4.2020.P0420XX

This publication is licensed under Creative Commons Attribution CC BY. 


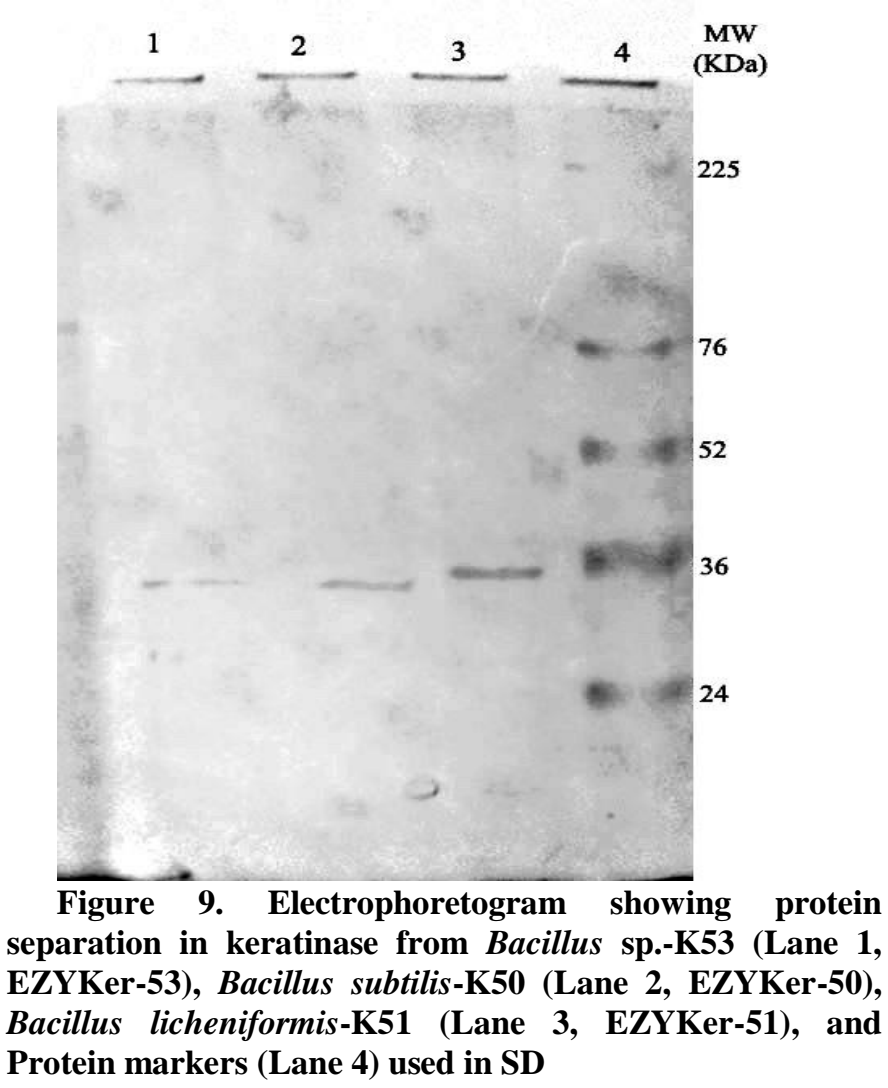

\section{K. Enzyme characterization}

1) Amino acid profiling of keratinase EZYKer-51

The result of the amino acid analysis of the purified EZYKer-51 is shown in Table 4. A total of 18 amino acids were obtained from the enzyme; Glutamate was found to be highest in quantity (18.23\%), followed by Alanine (14.92\%) and least was recorded in Tryptophan $(0.61 \%)$.

2) Effect of temperature on keratinase activity of purified keratinase

The result of the effect of temperature on keratinase activity of purified keratinase as presented in Table 5 shows that temperatures of $50{ }^{\circ} \mathrm{C}$ and $80{ }^{\circ} \mathrm{C}$ resulted in the highest and lowest enzyme activities of $20.63 \pm 0.47 \mathrm{U} / \mathrm{mL}$ and $1.03 \pm 1.68$ $\mathrm{U} / \mathrm{mL}$ respectively for EZYKer-50. Significant increase and subsequent significant reduction $(\mathrm{P} \leq .05)$ in enzyme activities were observed as temperature was increased from $30^{\circ} \mathrm{C}$ to $50^{\circ} \mathrm{C}$ and from $50^{\circ} \mathrm{C}$ to $80^{\circ} \mathrm{C}$ respectively. For EZYKer-51, temperature of $60^{\circ} \mathrm{C}$ resulted in highest keratinolytic activity of $26.31 \pm 0.64 \mathrm{U} / \mathrm{mL}$, while least activity of $10.25 \pm 1.22 \mathrm{U} / \mathrm{mL}$ was observed at $70^{\circ} \mathrm{C}$, beyond which no observable keratinase activity was detected. Activity was shown to increase significantly as temperature increased from $30^{\circ} \mathrm{C}$ to $50^{\circ} \mathrm{C}$. The observed increase in activity from $50^{\circ} \mathrm{C}$ to $60^{\circ} \mathrm{C}$ was not significant $(\mathrm{P} \leq 0.05)$. This was followed by a significant decrease in activity with further increase in temperature from $60^{\circ} \mathrm{C}$ to $70^{\circ} \mathrm{C}$. Temperatures of $50^{\circ} \mathrm{C}$ to $80^{\circ} \mathrm{C}$ also resulted in highest and lowest enzyme activities of $23.57 \pm 0.19 \mathrm{U} / \mathrm{mL}$ and $2.01 \pm 1.83 \mathrm{U} / \mathrm{mL}$ respectively for EZYKer-53. Enzyme activity was shown to increase significantly $(\mathrm{P} \leq 0.05)$ from $30^{\circ} \mathrm{C}$ to $50^{\circ} \mathrm{C}$, this was followed by a significant decrease in activity from $50^{\circ} \mathrm{C}$ to $70^{\circ} \mathrm{C}$. The observed difference in activity between $60^{\circ} \mathrm{C}$ and $70^{\circ} \mathrm{C}$ was not significant. An abrupt but significant reduction in activity (from $14.39 \pm 1.06 \mathrm{U} / \mathrm{mL}$ to $2.01 \pm 1.83 \mathrm{U} / \mathrm{mL}$ ) was shown with further temperature increase from $70^{\circ} \mathrm{C}$ to $80^{\circ} \mathrm{C}$.

3) Effect of pH on keratinase activity of purified keratinase

The result of the effect of $\mathrm{pH}$ on the activity of purified EZYKer-51, EZYKer-50 and EZYKer-53 is shown in Figure 10. No observable increase in enzyme activity was shown for EZYKer-50 as $\mathrm{pH}$ was increased from $\mathrm{pH} 7$ to $\mathrm{pH} 8$. Increase in $\mathrm{pH}$ from $\mathrm{pH} 8$ to $\mathrm{pH} 9$ resulted in a sharp increase in activity for EZYKer-50, while subsequent increase in $\mathrm{pH}$ from $\mathrm{pH} 9$ to pH 13 caused a gradual reduction in enzyme activity. Enzyme activities for EZYKer-51 and EZYKer-53 increased with $\mathrm{pH}$ from $\mathrm{PH} 7$ to $\mathrm{pH} 8$, further increase in $\mathrm{pH}$ resulted in gradual reduction in enzyme activities as $\mathrm{pH}$ was increased further to $\mathrm{pH} 8$ to $\mathrm{pH} 13$. The three enzymes show lowest activity at $\mathrm{pH}$ 7. EZYKer-50 showed highest enzyme activity of $20.63 \pm 0.43$ $\mathrm{U} / \mathrm{mL}$ at $\mathrm{pH} 9$ while EZYKer-51 and EZYKer-53 exhibited highest enzyme activity of $26.20 \mathrm{U} / \mathrm{mL}$ and $23.57 \pm 0.94 \mathrm{U} / \mathrm{mL}$ respectively at $\mathrm{pH} 8$.

Table 4. Amino Acid Profile of purified EZYKer-51

\begin{tabular}{ll}
\hline Amino acid & Amount $(\% \mathbf{w} / \mathbf{w})$ \\
\hline Glycine & 14.75 \\
Alanine & 14.92 \\
Serine & 5.39 \\
Proline & 5.83 \\
Valine & 5.72 \\
Threonine & 5.34 \\
Isoleucine & 4.79 \\
Leucine & 7.70 \\
Aspartate & 1.19 \\
Lysine & 8.68 \\
Methionine & 2.02 \\
Glutamate & 18.23 \\
Phenylalanine & 4.04 \\
Histidine & 1.53 \\
Arginine & 3.09 \\
Tyrosine & 4.37 \\
Tryptophan & 0.61 \\
Cystine & 0.74 \\
\hline
\end{tabular}


Table 5. Effect of temperature on keratinase Activity of purified keratinase

\begin{tabular}{llll}
\hline \multicolumn{4}{c}{ Keratinolytic Activity (U/mL) } \\
\hline $\begin{array}{l}\text { Temperature } \\
\left({ }^{\mathbf{0}} \mathbf{C}\right)\end{array}$ & $\begin{array}{l}\text { EZYKer-50 } \\
\text { (at pH 9) }^{\text {EZYKer-51 }}\end{array}$ & $\begin{array}{l}\text { EZYKer-53 } \\
\text { (at pH 8) }^{\text {Eat pH 8) }}\end{array}$ \\
\hline Room & $18.80 \pm 0.56^{\mathrm{e}}$ & $23.14 \pm 0.26^{\mathrm{b}}$ & $12.34 \pm 1.75^{\mathrm{b}}$ \\
Temperature & $16.73 \pm 0.82^{\mathrm{d}}$ & $23.90 \pm 0.09^{\mathrm{c}}$ & $15.08 \pm 0.32^{\mathrm{cd}}$ \\
30 & $18.22 \pm 0.33^{\mathrm{e}}$ & $24.29 \pm 0.08^{\mathrm{d}}$ & $19.38 \pm 0.29^{\mathrm{d}}$ \\
40 & $20.63 \pm 0.47^{\mathrm{f}}$ & $26.20 \pm 0.29^{\mathrm{e}}$ & $23.57 \pm 0.19^{\mathrm{e}}$ \\
50 & $15.36 \pm 0.65^{\mathrm{c}}$ & $26.31 \pm 0.64^{\mathrm{c}}$ & $14.00 \pm 0.16^{\mathrm{c}}$ \\
60 & $12.12 \pm 1.47^{\mathrm{b}}$ & $10.25 \pm 1.22^{\mathrm{a}}$ & $14.39 \pm 1.06^{\mathrm{c}}$ \\
70 & $1.03 \pm 1.68^{\mathrm{a}}$ & N. A & $2.01 \pm 1.83^{\mathrm{a}}$ \\
\hline 80 & & &
\end{tabular}

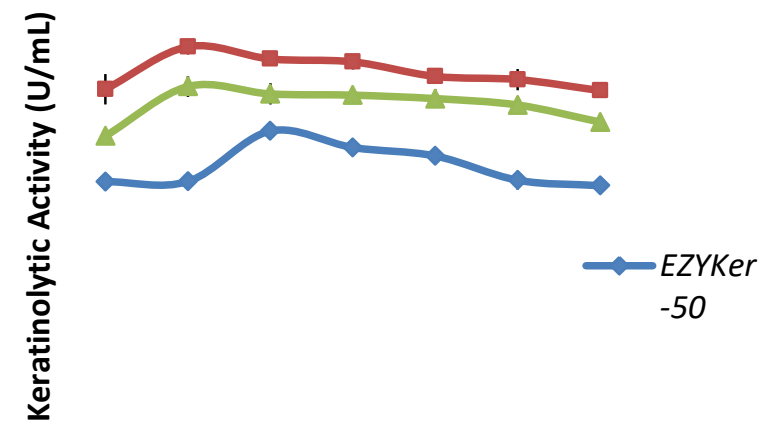

pH

Figure 10. Effect of $\mathrm{pH}$ on keratinolytic activity of purified keratinases

4) Effect of various metal ions on keratinase activity of purified keratinase

The result of the effect of various metal ions on purified keratinase is presented in Table 6. Among the six metal ions tested, $\mathrm{Ca}^{2+}$ gave highest keratinase activities across the three different concentrations $(0.1 \mathrm{mM}, 1 \mathrm{mM}$ and $10 \mathrm{mM})$, while $\mathrm{Hg}^{2+}$ showed lowest activity of $3.56 \pm 0.00 \mathrm{U} / \mathrm{mL}$ for EZYKer51 at $0.1 \mathrm{mM}$ concentration and no activity with other enzymes at all metal ion concentrations. $\mathrm{Cu}^{2+}$ also showed no observable enzyme activity at concentrations of $1 \mathrm{mM}$ and $10 \mathrm{mM}$ and also at $0.1 \mathrm{mM}$ for EZYKer-50, with very low activities of $5.27 \pm 0.00 \mathrm{U} / \mathrm{mL}$ and $2.19 \pm 0.79 \mathrm{U} / \mathrm{mL}$ at $0.1 \mathrm{mM}$ for enzymes EZYKer-50 and EZYKer-51 respectively. For all ions and at all concentrations, EZYKer-51 had the highest activities and least activities observed with EZYKer-50

Each metal ion showed significant reduction in keratinase activity for all the three enzymes when compared with the control except for EZYKer-50, EZYKer-51 and EZYKer-53 (with activity of $22.08 \pm 0.38 \mathrm{U} / \mathrm{mL}, 27.19 \pm 0.82 \mathrm{U} / \mathrm{mL}$ and $24.47 \pm 1.43 \mathrm{U} / \mathrm{mL}$ ) at $\mathrm{Ca}^{2+}$ concentrations of $0.1 \mathrm{mM}$. The observed increase in keratinase activities of $22.08 \pm 0.38 \mathrm{U} / \mathrm{mL}$ and $24.47 \pm 1.43 \mathrm{U} / \mathrm{mL}$ for EZYKer-50 and EZYKer-53 respectively when compared to the control at $0.1 \mathrm{mM} \mathrm{Ca}^{2+}$ was not a significant increase $(P=0.05)$ Only EZYKer-51 at 0.1 $\mathrm{mM} \mathrm{Ca}{ }^{2+}$ concentration gave enzyme activity that was significantly higher than activity of the control.

5) Effect of substrate concentration on keratinase activity
The result of the effect of substrate concentration on keratinase activity is presented in Figure 11. The result showed that the activity of EZYKer-50 increased rapidly with increase in substrate concentrations from $2.0 \%$ to $6.0 \%$. When the concentration of keratin was further increased beyond $6.0 \%$, there was no considerable increase in enzyme activity. EZYKer-51 and EZYKer-53 showed a rapid increase in keratinase activity as the substrate concentration increased from $2.0 \%$ to $8.0 \%$ after which there was no significant increase in the activity as concentration of Keratin increases.

6) Kinetic studies of the keratinolytic enzymes

The affinity of EZYKer-50, EZYKer-51 and EZYKer-53 enzymes was examined using the Lineweaver-Burke plot and the summary is presented on Table 7. For EZYKer-50, the enzyme reaction when the keratin concentration was varied from $2 \%$ to $12 \%$ gave $\mathrm{K}_{\mathrm{m}}$ and $\mathrm{V}_{\max }$ values of $8.73 \mathrm{mM}$ and $34.80 \mathrm{U} / \mathrm{mL}$ respectively. EZYKer-51 had $\mathrm{K}_{\mathrm{m}}$ and $\mathrm{V}_{\max }$ values of $25.60 \mathrm{mM}$ and $74.46 \mathrm{U} / \mathrm{mL}$ respectively while EZYKer-53 showed $\mathrm{K}_{\mathrm{m}}$ and $\mathrm{V}_{\max }$ values of $6.188 \mathrm{mM}$ and $29.57 \mathrm{U} / \mathrm{mL}$ respectively. 
Table 6. Effect of various metal ions on keratinase activity of purified keratinases

\begin{tabular}{|c|c|c|c|c|c|c|c|c|c|}
\hline \multirow{3}{*}{$\begin{array}{l}\text { Metal } \\
\text { ions }\end{array}$} & \multicolumn{9}{|c|}{ Keratinolytic Activity (U/mL) } \\
\hline & \multicolumn{3}{|c|}{ 0.1mM } & \multicolumn{3}{|l|}{$1 \mathrm{mM}$} & \multicolumn{3}{|l|}{$10 \mathrm{mM}$} \\
\hline & EZYKer-50 & EZYKer-51 & EZYKer-53 & EZYKer-50 & EZYKer-51 & EZYKer-53 & EZYKer-50 & EZYKer-51 & EZYKer-53 \\
\hline Control & $20.64 \pm 0.47^{\mathrm{c}}$ & $26.31 \pm 0.64^{\mathrm{c}}$ & $23.57 \pm 0.19^{d}$ & $20.64 \pm 0.47^{\mathrm{e}}$ & $26.31 \pm 0.64^{\mathrm{d}}$ & $23.57 \pm 0.19^{\mathrm{e}}$ & $20.64 \pm 0.47^{d}$ & $26.31 \pm 0.64^{\mathrm{d}}$ & $23.57 \pm 0.19^{\mathrm{e}}$ \\
\hline $\mathrm{Ca}^{2+}$ & $22.08 \pm 0.38^{\mathrm{c}}$ & $27.19 \pm 0.82^{\mathrm{d}}$ & $24.47 \pm 1.43^{\mathrm{d}}$ & $17.29 \pm 0.43^{\mathrm{d}}$ & $25.70 \pm 1.14^{\mathrm{d}}$ & $21.48 \pm 1.10^{\mathrm{e}}$ & $16.08 \pm 1.49^{c}$ & $20.30 \pm 1.05^{\mathrm{c}}$ & $18.29 \pm 0.74^{\mathrm{d}}$ \\
\hline $\mathrm{Mg}^{2+}$ & $15.05 \pm 1.15^{\mathrm{b}}$ & $23.60 \pm 0.55^{\mathrm{b}}$ & $15.86 \pm 0.45^{\mathrm{b}}$ & $12.00 \pm 0.79^{\mathrm{c}}$ & $20.39 \pm 0.44^{\mathrm{c}}$ & $14.29 \pm 1.27^{\mathrm{c}}$ & $12.23 \pm 1.10^{\mathrm{b}}$ & $20.02 \pm 1.86^{\mathrm{c}}$ & $12.03 \pm 1.56^{\mathrm{c}}$ \\
\hline $\mathrm{Fe}^{2+}$ & $13.01 \pm 1.03^{\mathrm{b}}$ & $22.24 \pm 0.67^{\mathrm{b}}$ & $15.29 \pm 0.25^{\mathrm{b}}$ & $7.20 \pm 1.07^{\mathrm{b}}$ & $15.20 \pm 1.38^{\mathrm{b}}$ & $11.29 \pm 2.25^{\mathrm{b}}$ & $0.00 \pm 0.00^{\mathrm{a}}$ & $7.08 \pm 1.30^{\mathrm{b}}$ & $5.00 \pm 0.22^{\mathrm{b}}$ \\
\hline $\mathrm{Mn}^{2+}$ & $18.58 \pm 0.71^{\mathrm{bc}}$ & $25.09 \pm 1.56^{\mathrm{c}}$ & $20.46 \pm 0.88^{c}$ & $16.29 \pm 0.33^{\mathrm{d}}$ & $23.20 \pm 0.32^{c}$ & $18.72 \pm 0.48^{\mathrm{d}}$ & $11.20 \pm 0.38^{\mathrm{b}}$ & $19.11 \pm 0.13^{\mathrm{c}}$ & $14.03 \pm 3.04^{\mathrm{c}}$ \\
\hline $\mathrm{Hg}^{2+}$ & $0.00 \pm 0.00^{\mathrm{a}}$ & $3.56 \pm 0.00^{\mathrm{a}}$ & $0.00 \pm 0.00^{\mathrm{a}}$ & $0.00 \pm 0.00^{\mathrm{a}}$ & $0.00 \pm 0.00^{\mathrm{a}}$ & $0.00 \pm 0.00^{\mathrm{a}}$ & $0.00 \pm 0.00^{\mathrm{a}}$ & $0.00 \pm 0.00^{\mathrm{a}}$ & $0.00 \pm 0.00^{\mathrm{a}}$ \\
\hline $\mathrm{Cu}^{2+}$ & $0.00 \pm 0.00^{\mathrm{a}}$ & $5.37 \pm 0.00^{\mathrm{a}}$ & $2.19 \pm 0.79^{\mathrm{a}}$ & $0.00 \pm 0.00^{\mathrm{a}}$ & $0.00 \pm 0.00^{\mathrm{a}}$ & $0.00 \pm 0.00^{\mathrm{a}}$ & $0.00 \pm 0.00^{\mathrm{a}}$ & $0.00 \pm 0.00^{\mathrm{a}}$ & $0.00 \pm 0.00^{\mathrm{a}}$ \\
\hline
\end{tabular}

Values

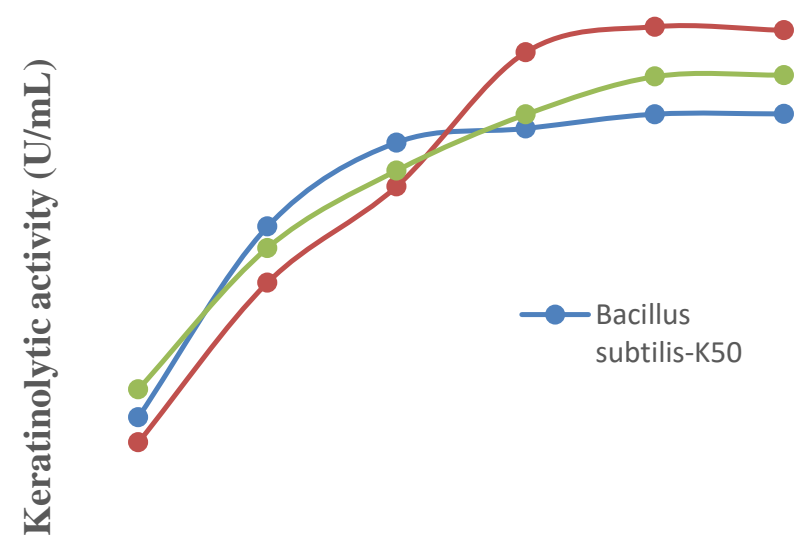

Keratin Concentration $(\% \mathrm{w} / \mathrm{v})$

Figure 11. Effect of keratin concentrations on keratinase activity by isolates 
Table 7. Summary of Lineweaver-Burke plot

\begin{tabular}{llc}
\hline Enzyme Code & Km $(\mathbf{m M})$ & $\begin{array}{c}\text { Vmax } \\
(\mathbf{U} / \mathbf{m L})\end{array}$ \\
\hline EZYKer-50 & 8.73 & 34.80 \\
EZYKer-51 & 25.60 & 74.16 \\
EZYKer-53 & 6.19 & 29.57 \\
\hline
\end{tabular}

\section{DISCUSSION}

Optimum keratinase production in this study was obtained at alkaline $\mathrm{pH}$ of 7.5, 7.8 and 7.2 for Bacillus subtilis-K50, Bacillus licheniformis-K51 and Bacillus sp.-K53 respectively. This report is similar to that obtained by Wakil and others [23], who observed optimum keratinase production by Bacillus licheniformis (E1) and Bacillus subtilis $\mathrm{B}(\mathrm{D} 1 \mathrm{~W})$ at $\mathrm{pH}$ 7.2. Bacillus could grow over a wide $\mathrm{pH}$ range of $\mathrm{pH} 7$ to $\mathrm{pH} 12$ while the production of keratinase is limited to $\mathrm{pH} 7$ to $\mathrm{pH} 10$ [24]. Keratinase production by the bacteria in this study is being favoured more in alkaline environment than acidic range and this could be due to the stable charge properties of substrate and stable enzyme conformation at alkaline $\mathrm{pH}$.

The optimal enzyme activity for the bacteria in this study over a broad range of temperature of $28{ }^{\circ} \mathrm{C}$ to $45^{\circ} \mathrm{C}$ was found to be at $37{ }^{\circ} \mathrm{C}$. Similar reports have also been documented for keratinolytic activity by Bacillus spp. at mesophilic temperatures [25]. Bacillus subtilis and Bacillus licheniformis are generally mesophilic bacteria with optimal growth temperature around $45^{\circ} \mathrm{C}$. Though they can survive at temperatures much higher than $37^{\circ} \mathrm{C}$, the optimal temperature for enzyme secretion for most Bacilli is around $37^{\circ} \mathrm{C}$ [26].

Optimum agitation rate for keratinase-producing bacteria in this study was found to be between $150 \mathrm{rpm}$ and $200 \mathrm{rpm}$, this optimum agitation rate is found to be consistent with previous works. in a report [23], shaking speed of $150 \mathrm{rpm}$ and $250 \mathrm{rpm}$ yielded maximum keratinase production in Bacillus licheniformis E1 and Bacillus subtilis D1. The shaking speed of $150 \mathrm{rpm}$ yielded maximum keratinase production by Bacillus sp. Fk-28 [27]. The higher agitation rate required by Bacillus subtilis-K50 compared to Bacillus licheniformis-K51 and Bacillus sp.-K53 may be a direct indication of a higher oxygen requirement by Bacillus subtilis-K50 for enzyme production. Generally, bacterial cells and substrates may not be well mixed at agitation speed of $100 \mathrm{rpm}$ and lower dissolved oxygen may result in lower keratinase production, therefore, increasing agitation of medium by increasing the shaking speed will provide high oxygen transfer rate which in turn supports the growth of cells. Nevertheless, very high shaking speed may have yielded low production of keratinase because too much dissolved oxygen in the medium and too high shear pressure represses the manufacture and release of keratinase.

The production of keratinase varied greatly with different carbon and nitrogen sources, among the carbon supplements, cellulose showed a slight increase over the non-supplemented control when the concentration of cellulose was varied at $1.4 \%$ in Bacillus subtilis-K50. Cellulose may not cause enzyme repression in keratinase produced by the bacteria being a complex carbohydrate. However, the addition of simple forms of carbohydrates like glucose may have caused a partial inhibition of keratinase production by Bacillus subtilis-K50,
Bacillus licheniformis-K51 and Bacillus sp.-K53. This reduction in production of enzyme may be as a result of catabolic repression by glucose which in many cases has been shown to have inhibitory effects on protease synthesis by microorganisms. A similar observation was made in another study by Dipak and others [28] who observed a profound effect on keratinase production with a keratinase yield of up to 1.5fold and lowest production on addition of glucose into the fermentation medium. However, glucose was found to have positive effect in the optimization of medium for keratinase production by Bacillus subtilis RGI [29].

According to Sivakumar and others [17], various bacteria may vary in their organic and inorganic predilection when it comes to the source of nitrogen for their growth and production of different enzymes although the utilization of complex sources of nitrogen is common for the production of alkaline proteases like keratinase [30]. Maximum keratinase production by Bacillus weihenstepanesis PKD with the supplementation of ammonium sulfate has also been reported [28]. Ammonium ions directly stimulate keratinase production, this may be a responsible factor in the high keratinase activity observed with Bacillus licheniformis-K51 in the presence of $\left(\mathrm{NH}_{4}\right)_{2} \mathrm{SO}_{4}$, but this was not the case with $\mathrm{NH}_{4} \mathrm{Cl}$ as low concentrations of $\mathrm{NH}_{4} \mathrm{Cl}$ may inhibit the growth of the organism. Nilegaonkar and others [31] reported that organic sources like peptone and yeast extract were found to suppress the protease production in certain bacterial strains and this may also be a reason why peptone in this study among others yielded low keratinase production.

Keratinase production by the bacteria in this study was lowest during the first $24 \mathrm{~h}$ of fermentation and reached maximum at 4 days, 7 days and 5 days of incubation for Bacillus subtilis-K50, Bacillus licheniformis-K51 and Bacillus sp.-K53 respectively. Maximum enzyme activities are known to be recorded at the exponential growth phase of bacteria which has been reported to vary among bacteria [28]. The difference in optimum incubation time recorded by the bacteria in this study may be in relation to the fact that bacteria do not show exact same growth phase due to their individual expression of genes in a culture. Related findings have also reported maximum enzyme production within 3-4 days after inoculation [32] and 6 days of inoculation [33].

The increase in specific activity for each enzyme after each purification step shows that the enzyme is not being lost during the purification process, it could also indicate that the enzyme is stable and is not losing its catalytic ability along each purification step, or the enzyme is not being degraded by any other protease in the crude and most importantly, it shows that the keratinolytic activity observed by the crude enzyme before purification is not actually due to mixtures of different enzymes with keratinase activity. The final purification step yielded an overall purification factor of 15.6, 13.1 and 14.1 for EZYKer-50, EZYKer-51 and EZYKer-53 respectively, however, total enzyme units was observed to decrease with increase in concentration of protein after each purification step. The concentration of the protein may be such that the keratinase is inhibited by an unknown but concentrated factor.

The detection of a single band through the SDS-PAGE confirmed the purification of the keratinase from each bacterium. The estimated molecular weight of keratinases produced by the bacteria strains in this study was found to be between $30-36 \mathrm{KD}$ which belongs to the molecular weight 
range of major keratinases, which varies from 20KDa to 50KDa [6]. This report is consistent with other reports on the molecular weights of keratinase from Bacillus pseudoformis FA30-01 at $27 \mathrm{KDa}$ [34], Bacillus sp. 50-3 at 27KDa [21] and Vibrio sp. $\mathrm{Kr} 2$ at $30.8 \mathrm{KDa}$ [35]. However, another study reports molecular weight as low as $18 \mathrm{KDa}$ belonging to the $S$ albidoflavus SK 1-02 [36]. Unusually high molecular weight of 200 KDa have also been reported for Kocuria rosea LPB-3 and F islandicum [37].

Amino acid analysis of the purified keratinase EZYKer-51 from this study share certain similarities with the keratinase studied by Sharaf and Khalil [38] which also contained high proportions of glutamic acid $(20.86 \%)$, glycine $(14.21 \%)$ and alanine $(14.52 \%)$ and moderate proportions of leucine $(8.59 \%)$, serine $(7.81 \%)$ and valine $(6.01 \%)$ and also showing threonine and phenyl alanine constituting less than $6 \%$, each. In a related report, Farag and Hassan [39] demonstrated that the purified keratinase obtained in their study comprises of 17 different amino acid residues which were high in glycine and glutamic acid.

Enzyme activities were observed in temperature range of $30{ }^{\circ} \mathrm{C}$ to $70{ }^{\circ} \mathrm{C}$ with results indicating maximal activities at 50 ${ }^{\circ} \mathrm{C}$ for EZYKer-50, EZYKer-53 and $60^{\circ} \mathrm{C}$ for EZYKer-51. Most keratinases exhibit optimum enzyme activity between 30 ${ }^{\circ} \mathrm{C}$ and $80{ }^{\circ} \mathrm{C}$, for example, keratinase from B. pseudofirmus AL-89 is $60{ }^{\circ} \mathrm{C}$ to $70{ }^{\circ} \mathrm{C}$ [40], Nocardiopsis sp. TOA-1 is $60{ }^{\circ} \mathrm{C}$ [41], and keratinase from Brevibacillus brevis was optimally active at $40{ }^{\circ} \mathrm{C}$ [2]. Exceptionally high temperature optimum of $100{ }^{\circ} \mathrm{C}$ from Fervidobacterium islandicum AW-1 has also been reported [6].

The enzyme activity for the purified keratinase was studied over a wide range of $\mathrm{pH}(\mathrm{pH} 7.0$ to $\mathrm{pH} 13)$, the optimum $\mathrm{pH}$ was found to be $\mathrm{pH} 9$ for keratinase from Bacillus subtilis-K50 and pH 8 for Bacillus licheniformis-K51 and Bacillus sp.-K53. These $\mathrm{pH}$ optima have been found to be consistent for keratinases in most reports. Keratinase produced by Bacillus weihenstephansis [28] has been shown to be active in the $\mathrm{pH}$ range of $6.0-9.0$ with optimal activity of $\mathrm{pH} 8$. In a study by $\mathrm{Xu}$ and others [42], Bacillus licheniformis K-19 was shown to have optimal keratinolytic activity at $\mathrm{pH} 7.5$ to 8.0. Most keratinase are active at neutral to alkaline conditions, from $\mathrm{pH}$ 7.0 to $\mathrm{pH} 9.5$ [25], and tis was found on be true for fungal keratinases [22]. The optimum $\mathrm{pH}$ of Aspergillus flavus K-03 was recorded at $\mathrm{pH} 9.0$ while optimum $\mathrm{pH}$ for Aspergilus oryzae was 7.0 [22].

While higher $\mathrm{pH}$ has been indicated with Bacillus licheniformis enzyme showing a wide range of $\mathrm{pH}$ activity with optimum $\mathrm{pH}$ of 11.0 [43], few of extreme alkalophilic optima $\mathrm{pH}$ have also been reported with Bacillus halodurans showing $\mathrm{pH}$ optima for keratinase at $\mathrm{pH} 12$ [44]. An alkalophilic Nocardiopsis sp. TOA-1 has also been reported to produce keratinase with alkalophilic optimum at $\mathrm{pH} 12.5$ [41].

From this study, only the addition of $\mathrm{Ca}^{2+}$ gave enzyme activity that was observed to be higher than activity of the control without metal inclusions. Some divalent cations promote the active conformation of keratinase thus increasing their catalytic rate. From the report of effect of metal ions on keratinase activity, most keratinases are activated in the presence of metal ions $\mathrm{Ca}^{2+}, \mathrm{Mn}^{2+}$ and $\mathrm{Mg}^{2+}$ [45]. Another reason for the increase in protease activity with $\mathrm{Ca}^{2+}, \mathrm{Mn}^{2+}$, $\mathrm{Mg}^{2+}$ may be that these metal ions confer protection for the enzyme against denaturation by heat, as a result performing a vital function in the maintenance of its active conformations [46]. Largely, keratinases isolated from Gram positive bacteria are mostly serine proteases which are known to possess two $\mathrm{Ca}^{2+}$ active sites, and the absence of calcium ions from these sites is related to a notable reduction in enzymatic activity, therefore, the role of calcium ion $\left(\mathrm{Ca}^{2+}\right)$ in this study is most likely associated with the stability of the activate forms of the three keratinases. As mentioned earlier, it was expected that the keratinase in this study will be activated by $\mathrm{Mn}^{2+}$ and $\mathrm{Mg}^{2+}$, rather, their addition resulted in slight inhibitions of the enzymes. According to Tapia and Simones [47], this inhibition might be as a result of the presence of free cysteine at the binding site or near the active site of the enzyme. Addition of $\mathrm{Hg}^{2+}$ in this work showed strong inhibitory effects on keratinolytic activities of the three keratinase enzymes. It has been suggested that the enzyme inhibition as a result of the presence of $\mathrm{Hg}^{2+}$ is not only associated with the involvement of thiol groups but a direct consequence of the influence of tryptophan residues or with the carbonyl group of amino acids in the enzyme [48]. Reports consistent with the strong inhibitory effects of $\mathrm{Hg}^{2+}$ on the keratinase in this study includes the strong inhibition of keratinase from Bacillus pumulis CBS by $\mathrm{Hg}^{2+}$ and complete inhibition of keratinase from Brevibacillus brevis US575 [2].

The high $\mathrm{K}_{\mathrm{m}}$ and Vmax values observed for the three enzymes in this study followed the classical Michaelis-Menten kinetics showing a relatively large binding affinity. EZYKer-51 showing the highest $\mathrm{K}_{\mathrm{m}}$ value and consequently highest $\mathrm{V}_{\max }$ values will require higher substrate concentrations for enzyme saturation and to reach maximum rate of reaction while compared to EZYKer-50 and EZYKer-53 with lower $\mathrm{K}_{\mathrm{m}}$ and $\mathrm{V}_{\max }$ values. A relatively lower $\mathrm{K}_{\mathrm{m}}$ value of $1.5 \mathrm{mM}$ has been recorded for keratinase [2], while in the same report, $\mathrm{V}_{\max }$ of 52 $\mathrm{U} / \mathrm{mL}$ was obtained.

\section{CONCLUSION}

This work showed that the keratinases produced by the Bacillus strains possess prominent alkaline, metalloprotease characteristics. The keratinases produced were adequately purified by ammonium sulphate precipitation and Sephadex G75 chromatographic technic to produce single bands on SDSPAGE. They were produced optimally from already isolated strains of Bacillus using feather broth medium at alkaline $\mathrm{pH}$ and mesophilic temperatures within 4-7 days. Production of the enzyme can be further induced with the addition of cellulose and $\left(\mathrm{NH}_{4}\right)_{2} \mathrm{SO}_{4}$.

Keratinase production by Bacillus subtilis-K50, Bacillus licheniformis-K51 and Bacillus sp.-K53 can be carried out in the optimized parameters which were tested in this study in applications that requires keratin hydrolysis.

\section{REFERENCE}

[1] S. Singh, and B. K. Bajaj, Potential application spectrum of microbial proteases for clean and green industrial production Energ Ecol Environ 2(6) 370-386, 2017 doi.org/10.1007/s40974017-0076-5.

[2] N. Z. Jaouadi, H. Rekik, A. Badis, S. Trabelsi, M. Belhoul, A. B. Yahiaoui, H. Aicha, A. Toumi, S. Bejar and B. Jaouadi, Biochemical and molecular characterisation of a serine keratinase from Brevibacillus brevis US575 with promising keratinbiodegradation and hide-dehairing activities. Public Library of Science. 2 72-726, 2013. Doi: 10.1371/journal.pone.0076722 
[3] L. Lange, Y. Huang and P. K. Busk, Microbial decomposition of keratin in nature - a new hypothesis of industrial relevance. Appl Microbiol Biotechnol. 100(5) 2083-2096, 2016. Doi: 10.1007/s00253-015-7262-1

[4] B. Srinivasan, K. M. Senthil, R. Karthikeyan, R. Kumar, S. Kirubanandan, S. K. Ravichandran, and P. Sehgal, Purification and characterisation of an extracellular keratinase from a hornmeal-degrading Bacillus subtilis MTCC (9102). World J Microbiol Biotechnol. 24 2741-2745, 2008. Doi.org/10.1007/s11274-008-9782-7

[5] A. Onifade, N. Sane, A. Musalam and S. Zabane, Potential for biotechnological application of keratin-degrading microrganisms and for nutritional improvements of feather Bioresour. Technol. 66 2-12. 1998. doi.org/10.1016/S0960-8524(98)00033-9

[6] G. W. Nam, W. Lee-Dong, N. J. Lee, B. Kim, C. Young and E. H. Choe, Native feather degradation by Fervidobacterium islandicum AW-1, a newly isolated keratinase-producing thermophilic anaerobe. Arch Microbiol 178 538-547, 2002 doi.org/10.1007/s00203-002-0489-0

[7] G. Ramakrishnaiah, S. Mustafa and S. Gunji, Studies on Keratinase Producing Fungi Isolated from Poultry Waste and their Enzymatic Activity J.microbiol 3 148-151, 2013 doi:10.5923/j.microbiology.20130304.04

[8] A. Nurdiawati, B. Nakhshiniev, I. Zaini, N. Saidov, F. Takahashi and K. Yoshikawa, Characterization of potential liquid fertilizers obtained by hydrothermal treatment of chicken feathers. Environ Prog Sustain Energ. 37(1) 375-382, 2017 doi.org/10.1002/ep.12688.

[9] R. Gupta, R. Rajput, R. Sharma and N. Gupta Biotechnological applications and prospective market of microbial keratinases. Appl Microbiol Biotechnol 97 9931-9940, 2013 doi.org/10.1007/s00253-013-5292-0

[10] V. K. Gupta, D. Thangadurai, G. D. Sharma and R. Gaur, Microbial keratinases: characteristics, biotechnological applications and potential... The Handbook of Microbial Bioresources, Chapter: 10. CAB International pp.634-674, 2016.

[11] C. S. Vigneshwaran, T. Shanmugam and K. Sathish, Screening and characterization of keratinase from Bacillus licheniformis isolated from Namakkal poultry farm. Researcher 2(4) 59-96, 2010.

[12] X. Lin, L. Chung-Ginn, S. Ellen and S. Jashon, Purification and Characterisation of a Keratinase from a Feather-Degrading Bacillus licheniformis Strain. Appl Environ Microbiol 58:(10) 3271-3275, 1992.

[13] K. Wawrzkiewiez, T. Wolski and J. Lobarzewski, Screening the keratinolytic activity of dermatophytes in vitro. Mycopathologia. 114 (1) 1-8, 1987, doi.org/10.1007/BF00436684

[14] H. Gradisar, S. Kern and J. Friedrich, Keratinase of Doratomyces microspores. Appl Microbiol Biotechnol. 53 196-200, 2000, doi.org/10.1007/s002530050008

[15] O. H. Lowry, N. J. Rosebrogh and R. Randal, Protein measurement with phenol reagent. J Biol Chem. 193 265-275, 1951.

[16] C. G. Cai, M. G. Lou, and X. D. Zheng, Keratinase production and keratin degradation by a mutant strain of Bacillus subtilis, J Zhejiang Univ. 9 60-66, 2008, doi.org/10.1631/jzus.B061620

[17] T. Sivakumar, T. Shankar, V. Thangapand and V. Ramasubram, Optimization of cultural condition for keratinase production using Bacillus cereus TS1. Insight Microbiol 3(1) 1-8 2012, Doi: 10.5567/IMICRO-IK.2013.1.8

[18] M. Dixon and E. C. Webb, Enzymes (2nd ed.) Longmans, London, 1971.

[19] B. D. Hames, Gel Electrophoresis of Proteins: A Practical Approach3 Oxford University Press New York ISBN 1998. 0199-63641-9

[20] U. K. Laemmli, Cleavage of structural proteins during the assembly of the head of bacteriophage T4. Nature 227 680-685, 1970.
[21] J. Zhang, Y. Li, L. Jiashen, Z. Zhao, X. Liu, Z. Li, Y. Han, J. Hu and $A$. Chen, Isolation and characterisation of biofunctional keratin particles extracted from wool wastes. Powder Technol. 246 356-362, 2013, doi.org/10.1016/j.powtec.2013.05.037

[22] H. A. Thanaa, H. Nadia and A. Latifaa, Purification and property of extracellular keratinase from feathers-degradation by A. oryzae NRLL-447. J Appl Sci Environ Manage 6(2) 123-128, 2011.

[23] S. M. Wakil, M. T. Dada and A. A. Onilude, Isolation and Characterisation of Keratinase-Producing Bacteria from Poultry Waste. J Pure Appl Microbiol. 5(2) 567-580, 2011.

[24] M. S. Hossain, A. K. Azad, S. M. Abu. G. Mostafa and M. M. Hoq, Production and partial characterisation of feather degrading keratinolytic serine protease from Bacillus licheniformis MZK-3. Int J Biol Sci. 7 599-606. 2007, Doi: 10.3923/jbs.2007.599.606

[25] H. A. El-Refai, M. A. Abdel-Naby, M. H. El-Arabey and A. F. Abdel-Fattaih, Improvement of the newly isolated B. pumilus strain FH9. Process Biochem. 40(7) 2324-2333, 2005.

[26] S. Yamamura, Y. Morita, Q. Hasan, S. R. Rao, Y Murakami, K. Yokoyama and E. Tamiya, Characterisation of a new keratin degrading bacterium isolated from deer fur, J Bioscie Bioeng.. 93 595-600. 2002, doi.org/10.1016/S1389-1723(02)80243-2

[27] P. Dakrong and W. Suntornsuk, Production of Keratinase by Bacillus sp. FK 28 Isolated in Thailand. Kasetsart J Nat Sci. 35 72-79, 2001.

[28] K. S. Dipak, A. Das, H. Thatoi, C. K. Mondal and P. Mohapatra, Keratinase Production and Biodegradation of Whole Chicken Feather Keratin by a Newly Isolated Bacterium Under Submerged Fermentation. Appl Biochem Biotechnol. 167 10401051, 2012, doi.org/10.1007/s12010-011-9527-1

[29] P. Ramnani and R. Gupta, Keratinases vis-à-vis conventional proteases and feather degradation. World J Microbiol Biotechnol 23 (11) 1537-1540, 2007, Doi: 10.1007/s11274-007-9398-3

[30] R. S. Prakasham, C. S. Rao and P. N. Sarma, Green gran husk and inexpensive substrate for alkaline protease production by Bacillus sp in solid state fermentation. Bioresour Technol. 97 1449-1454, 2006, Doi: 10.1016/j.biortech.2005.07.015

[31] S. S. Nilegaonkar, V. P. Zambare, P. P. Kanekar, P. K. Dhakephalkar and S. S. Sarnaik, Production and partial characterisation of dehairing protease from Bacillus cereus MCM B-326. Bioresour Technolechnol. 98 1238-1245, 2007, Doi: 10.1016/j.biortech.2006.05.003

[32] J. M. Kim, W. J. Lim and H. J. Suh, Feather-degrading Bacillus sp. from poultry wastes. Process in Biochem. 37(3) 287-291, 2001, Doi: 10.1016/S0032-9592(01)00206-0

[33] S. Nagal, N. Kango and P. Chandra-Jain, Production of alkaline protease from Elizabeth kingia meningoseptica KB042 using chicken feathers. Ann Microbiol. 60 629-635, 2010, Doi:10.100710.1007/s13213-010-0101-9

[34] M. Kojima, M. Kana, M. Tominag, S. Inoub and K. Horikosh, Isolation and characterisation of a feather-degrading enzyme from B. pseudofirmus strain FA30-01. Extremophiles 10229 235, 2006, doi.org/10.1007/s00792-005-0491-y

[35] S. Sangali and A. Brandelli, Feather keratin hydrolysis by a Vibrio sp. strain kr2. J Appl Microbiol. 89(5) 735-743, 2001, doi.org/10.1046/j.1365-2672.2000.01173.x

[36] R. R. Chitte, V. K. Nalawade, Keratinolytic activity from the broth of a feather-degrading thermophillic Streptomyces Thermoviolaceus strain SD8. Lett Appl Microbiol. 28 (2)131136, 2002, doi.org/10.1046/j.1365-2672.1999.00484.x

[37] C. Bernal, L. Cairo and N. Coello, Purification and characterisation of a novel exocellular keratinase from Kocuria rosea. Enzyme Microb Technol. 38 49-54, 2006, Doi: 10.1016/j.enzmictec.2005.02.021

[38] E. F. Sharaf and N. M. Khalil, Keratinolytic activity of purified alkaline keratinase produced by Scopulariopsis brevicaulis and its amino acids profile. Saudi J Biol Sci. 18(2) 117-121, 2011, Doi: $10.1016 /$ j.sjbs.2010.12.011

[39] A.M. Farag and M. A. Hasan, Purification, characterisation and immobilization of a keratinase from Aspergillus orizae. Enzyme 
Microb Technol. 34(2) 85-93, 2004, Doi: 10.1016/j.enzmictec.2003.09.002

[40] A. Gessesse, R. Hatti-Kaul, B. Gashe and B. Mattiasson, Novel alkaline proteases from alkaliphilic bacteria grown on chicken feather. Enzyme Microb Technol. 32 519-524, 2003, doi.org/10.1016/S0141-0229(02)00324-1

[41] S. Mitsuiki, M. Ichikawa, T. Oka, M. Sakai, Y. Moriyama, Y. Sameshima, M. Goto and K. Furuka, Molecular characterisation of a keratinolytic enzyme from an alkaliphilic Nocardiopsis sp TOA-1. Enzyme Microb Technol 34(5) 482-489, 2004, Doi: 10.1016/j.enzmictec.2003.12.011

[42] X. Xu, D. A. Elder, R. Elenitsa, B. L. Johnson and G. E. Murphy, Lever's Histopathology of the Skin. Int J Pharma Biol Sci. 3 (2) 125-130, 2008

[43] H. Korkmaz, H. Hür,,S. di and R. Nçer, Characterisation of alkaline keratinase of Bacillus licheniformis strain HK-1 from poultry waste. Ann Microbiol. 54 201-211, 2004.

[44] H. Takami, Y. Nogi and K. Horikoshi, Reidentification of the keratinase-producing facultatively alkalophilic Bacillus sp. AH-
101 as Bacillus halodurans. Extremophiles. 3 293-296, 2009, Doi: $10.1007 / \mathrm{s} 007920050130$

[45] S. Riessen, G. Antranikian, Isolation of T. keratinophilus sp. Strain NOV; a novel thermophilic, anaerobic bacterium with keratinolytic activity. Extremophiles 5 398-409. 2001, doi.org/10.1007/s007920100209

[46] C. G. Kumar and H. Takagi, Microbial alkaline proteases: from bioindustrial viewpoint. Biotechnol Adv. 17 287-291, 2011, doi.org/10.1016/S0734-9750(99)00027-0

[47] D. M. Tapia and J. Contiero J, Production and partial characterisation of keratinase produced by a microorganism isolated from poultry processing plant wastewater. Afri $\mathbf{J}$ Biotechnol. 7 (3)296- 300, 2008.

[48] W. Suntornsuk and L. Suntornsuk, Feather degradation by Bacillus sp FK 46 in submerged cultivation. Bioresour. Technol. 86 239-243, 2003, Doi: 10.1016/S0960-8524(02)00177-3 